\title{
EL EXILIO DE LOS BORBÓNICOS VALENCIANOS
}

\author{
ENRIQUE GIMÉNEZ LÓPEZ
}

Universidad de Alicante

El P. Nicolás Belando decía en su Historia Civil que, tras la entrada de Basset en Valencia y la rendición de la capital, «se dio el permiso para que saliese el que quisiera de la ciudad, y lo ejecutaron el arzobispo, con grande número de títulos y nobles, y de los ministros togados el regente y once de los oidores, habiendo ejecutado lo mismo, antes de la rendición, el virrey» ${ }^{\perp}$. Según la nómina de los valencianos que partieron al exilio, y que elaboró el Consejo de Aragón a fines de $1706^{2}$, fueron 433 los que abandonaron el Reino, aunque su número, en la realidad, fue muy superior. Además del arzobispo Folch de Cardona, tres canónigos valencianos, dos alicantinos y otros dos de Xátiva figuraban entre las dignidades eclesiásticas. Eran 39 los eclesiásticos seculares, y 96 los regulares, distribuidos entre franciscanos (27), dominicos (17), jerónimos (17), jesuitas (15), trinitarios descalzos (14), agustinos (5) y carmelitas calzados (1).

Tal y como señalaba Belando, eran 12 los magistrados de la Audiencia que abandonaron Valencia pues únicamente el oidor civil Manuel Mercader y Calatayud, natural de la comarca de la Marina ${ }^{3}$, se había sumado a la causa del Archiduque y, por ello, nombrado regente de la Audiencia austracista en los primeros días de $1706^{4}$. También

1. Nicolás BELANDO: Historia civil de España, sucesos de la guerra y tratados de paz, desde el año de mil setecientos, hasta el de mil setecientos y treinta y tres, Madrid 1740, Vol. I, p. 193.

2. A. H. N. Consejos Leg. 17.827 Nómina de las Dignidades, Ministros, Caballeros, Religiosos y Particulares del Reino de Valencia que, por no sujetarse a otro Dominio que al de la Majestad del Sr. Felipe V (que Dios guarde) abandonaron sus casas y haciendas, hecha en ejecución del Decreto de V. M. publicado en 9 de los corrientes.

3. Carmen PÉrez APARICIO: «La Guerra de Sucesión en España», en La transición del siglo XVII al XVIII, vol. XXXVIII de la Historia de España de Ramón Menéndez Pidal, Madrid 1994, p. 393. El 18 de agosto de 1717 el Archiduque le concedió la gracia de Sumiller de corina, en Francisco de CASTELLVI: Narraciones históricas, Madrid 1998, vol. II, p. 432.

4. Carmen PÉREZ APARICIO: «La política de represalias y confiscaciones del Archiduque Carlos en el País Valenciano, 1705-1707», en Estudis 17 (1991), pp. 149-196, especialmente pp. 159-160. 
habían salido de territorio valenciano los gobernadores de Valencia, Xátiva y Alicante, el asesor de los de Castellón y Valencia, el procurador patrimonial de la gobernación alicantina, y los tenientes de gobernador de Valencia y Xátiva. Lo habían hecho así mismo el baile general de Alicante, acompañado de su teniente, tesorero y racional, y en el tribunal de la bailía de Valencia su asesor y el receptor. Igualmente habían dejado Valencia el inquisidor más antiguo del tribunal y el procurador general de la orden de Montesa. La nobleza titulada había abandonado Valencia casi en su totalidad, acompañados de sus familias: la condesa de Castrillo, el conde de Parcent, el de Villanueva con su mujer, el del Real con su mujer y dos hijos, el de Castellar, el de Almenara, con su esposa y tres hijos, al igual que el de Carlet, y los marqueses de Malferit, Bélgida, con sus tres hijos, el de Albaida, con su esposa y cuatro hijos, y el de la Escala, con su mujer. Se sumaban a ellos 49 caballeros de la ciudad de Valencia, 19 de Alicante, 17 de Onteniente, 10 de Xátiva y otros de 6 de diversas localidades, como Cocentaina, Alcoy, Beniganim, Murviedro o Cálig, Se contabilizaron 22 ciudadanos, algunos del estamento militar y otros abogados, y 107 particulares, de diversas poblaciones, entre los que se hallaban los gobernadores de los señoríos de Catarroja ${ }^{5}$, Castellón de Rugat y Buñol, y los justicias de Alicante y Enguera, con sus respectivos tenientes. Se unían a todos ellos 20 mercaderes franceses de Valencia y Alicante, de los que seis pasaron a Madrid, dos a la población manchega de El Provencio y otros a Albacete y distintos lugares de Castilla la Nueva, aunque es sabido que otros fueron deportados a Barcelona ${ }^{7}$.

Las circunstancias de su salida de Valencia, sus peripecias en el exilio castellano, la situación, con frecuencia desesperada, en la que se encontraron, faltos de medios para su subsistencia, en condiciones de miseria y necesidad, la ayuda que recibieron de Felipe V, los cargos y mercedes que solicitaron como premio a su fidelidad y a sus sacrificios, y las gracias que obtuvieron del monarca, suponen una posibilidad de aproximación a la realidad del felipismo valenciano en los años trágicos de la guerra y la primera postguerra.

El 14 de enero de 1707 Felipe V, ante las muchas «instancias con motivo de las miserias que están padeciendo» los valencianos leales asilados en la Corte, ordenó que los 141.577 rls. que habían sido confiscados en Madrid a valencianos austracistas, se repartieran «para que no lleguen a morir de hambre y experimenten en algún modo los efectos de su Real conmiseración, en atención a lo que han padecido y perdido». El 14

\footnotetext{
5. Vicente Porcella, refugiado en Madrid con su mujer e hijos, uno de ellos tullido en un cama, recibió 480 rls. de socorro en abril de 1707, en A. H. N. Consejos Leg. 18.450 Consulta del Consejo de Aragón. Madrid 14 de abril de 1707.

6. El castellonense Jaime Andreu, que había sido soldado en Cataluña en las guerras hispano-francesas del reinado de Carlos II, había accedido a la Gobernación de Buñol para acabar con el bandolerismo. Abandonó territorio valenciano acompañando al Virrey Villagarcia, pero al llegar a Siete Aguas Antonio del Valle le ordenó que regresara a Buñol, y se retiró definitivamente cuando abandonaron Valencia las tropas del Conde de las Torres, residiendo en Madrid desde octubre de 1706, en A. H. N. Consejos Leg. 18.450 Memorial de Jaime Andreu.
}

7. Carme Pérez APARIClo: De l'alçament maulet al triomf botifler, Valencia 1981, p. 52. 
de abril el Consejo de Aragón elaboró un listado de nombres, donde figuraba la cantidad asignada a cada sujeto ${ }^{8}$. Tras el éxito de Almansa y la recuperación de Valencia el 8 de mayo, el Consejo elaboró una Memoria de los sujetos a quienes V. M. puede servirse mandar socorrer, que en realidad era una lista complementaria de la anterior, y que donaba ayudas en metálico para que pudieran restituirse a sus casas. ${ }^{9}$. El proceso seguido para la elaboración de los listados y la concesión de ayudas fue descrito por el presidente del Consejo de Aragón, Rodrigo Manrique de Lara, conde de Frigiliana, a Grimaldo en carta fechada el 15 de diciembre de 1707, cuando prácticamente todo el trámite de reparto de ayudas ya había finalizado. Al igual que la nómina elaborada a fines de 1706, Manrique de Lara había dividido a los valencianos exilados en Ministros, Títulos, Caballeros, Particulares y Eclesiásticos, con especial consideración hacia los dos primeros grupos, que habían recibido la ayuda mayor, cifrada de media en unos 3.800 rls. Para las restantes tres categorías, las cantidades oscilaron, en función de informes previos, entre los 2.000 rls. que había recibido el que más, y los 500 rls. el que menos. No había sido fácil realizar esas discriminaciones en los socorros: «he procurado informarme exactísimamente de los que hoy se hallan en la Corte habiendo dejado sus casas y conveniencias siendo difícil pesar cuales sean los que padecen mayor necesidad, porque siendo en todos igual la razón de no tener hacienda que socorrerse y haber perdido la que poseían no hay alguno que no considere por el mayor y más justificado su ahogo» ${ }^{10}$.

\section{EL BLOQUE DE LA MAGISTRATURA}

La casi unanimidad de la magistratura valenciana por mantenerse leal a Felipe $V$ tiene su explicación en la estrecha y duradera vinculación que sus miembros tenían con la administración real en Valencia, como asesores de las distintas gobernaciones y su intervención, por comisión de los virreyes, en la persecución del bandolerismo y en la represión del levantamiento campesino en La Marina de 1693, que tanta similitud tenía con los acontecimientos de $1705^{11}$. Pedro José Borrull había sido catedrático durante 16 años antes de ocupar la asesoría del justicia criminal de Valencia y ejercer como asesor del Portanveus del General Gobernador de la capital. Esta experiencia fue determinante para su elección el 12 de septiembre de 1689 para oidor de causas criminales en la Audiencia foral, interviniendo en la represión de la Segunda Germanía ${ }^{12}$. Andrés Montserrat Crespi de Valldaura fue gobernador de Castellón durante el virreinato del marqués de Castelrodrigo, y se distinguió en la represión del bandolerismo

8. A. H. N. Consejos Leg. 18.476 Consulta del Consejo de Aragón, Madrid 14 de abril de 1707.

9. A. H. N. Consejos Leg. 18.476 Consulta del Consejo de Aragón, Madrid 15 de junio de 1707.

10. A. H. N. Consejos Leg. 18.476 Manrique de Lara a Grimaldo, Madrid 15 de diciembre de 1707.

11. Carmen PÉREZ APARICIO: «Reivindicaciones antiseñoriales en el País Valenciano. De la Segunda Germanía a la Guerra de Sucesión», en Estudis 24 (1988), pp. 247-279.

12. Sebastián García MarTinez: Valencia bajo Carlos II, Villena 1991, pp. 566-568. 
en su demarcación ${ }^{13}$. Bruno Salcedo Vives fue comisionado en 1679 por el virrey Veragua para la persecución de bandidos, desde 1687 «se empleó seis años ejecutando prisiones de la mayor consecuencia al real servicio» como asesor del Portanveus de la Gobernación de Orihuela ${ }^{14}$, y Castelrodrigo le volvió a comisionar para reprimir sediciosos en $1693^{15}$. Cuando se hallaba huido de Valencia en 1706, pasando grandes dificultades, Salcedo recordaba que de las dietas de la persecución de delincuentes y bandidos todavía se le adeudaban 1.260 libras $^{16}$. El alcoyano Francisco Descals fue asesor de las Gobernaciones de Xátiva, entre 1681 y 1694, y de Orihuela entre 1694 y $1704^{17}$. Durante su estancia en Xátiva fue comisionado en 1684 por el virrey conde de Cifuentes, y en 1693 Castelrodrigo le encomendó «recibir información de testigos contra los reos») del levantamiento campesino de aquel año en La Marina ${ }^{18}$. Pedro Doménech, recibió en 1794 el encargo del virrey de erradicar el juego ${ }^{19}$, y dos años después era designado asesor de la Gobernación de Valencia, cargo que también desempeñó entre julio de 1701 y agosto de 1704 Francisco Despuig Mercader. Quizá la experiencia más espectacular fuera la vivida por el magistrado alicantino Damián Cerdá, cuando cubría el cargo de asesor de la Gobernación de Orihuela. En diciembre de 1781 fue comisionado por el virrey Aguilar para perseguir forajidos, y el 12 de noviembre de 1688 sufrió un atentado cuando se hallaba en su casa de Alicante por el bandolero Salvador Berenguer, un labrador de Novelda que había formado partida y actuaba en aquel término y en los de Alicante y Villajoyosa, y del que resultó herido por arma de fuego un criado del propio Cerdá20.

En el periodo inmediatamente anterior a la sublevación austracista alguno de estos magistrados tuvieron encargos relevantes. El ya citado Damián Cerdá, asesor de la Gobernación de Xátiva en 1704, pasó a la villa de Altea, con comisión del virrey Villagarcía, para averiguar el recibimiento que la población de distintos pueblos de La Marina había dispensado a la Armada aliada durante su ancoraje en aquella bahía ${ }^{21}$. Sus informes no ayudaron a que el virrey tomara conciencia de los peligros de la situación, pues en mayo de 1704, tras recorrer las tierras de La Marina, Cerdá había transmitido la tranquilidad que, suponía, existía en la comarca: «...habiendo en pocos meses, por los encargos de V. E., transitado por los lugares más principales de las montañas, y hasta Vall de Guadalest, Villajoyosa, Finestrat, Relleu y otros, les considero con gran quietud y seguridad sin que haya podido comprender la menor noticia de infidelidad ni desasosiego,

13. Ibidem, p. 253.

14. Teresa CANET APARISI: La Magistratura Valenciana (s. XVI-XVII), Valencia 1990, p. 184.

15. Sebastián Garcia Martinez: Op. Cit. p. 247.

16. A. H. N. Consejos Leg. 18.476 Memorial de D. Bruno Salcedo solicitando socorro.

17. Teresa CANet Aparisi: Op. Cit. p. 185.

18. Sebastián García MARTíneZ: Op. Cit. pp. 232 y $279,567-8$ y $580-1$.

19. Ibidem. p. 256.

20. Ibidem. pp. 225 y 422.

21. Enrique GIMÉNEZ LOPEZ: «El desembarco aliado en Altea en 1704 y el Virrey Marqués de Villagarcia», en Homenaje al Dr. D. Sebastián Garcia Martinez, Valencia 1988, vol. II, pp. 269-284. 
ya en tanto tiempo me persuado se hubiera descubierto alguna centella ${ }^{22} \gg$. También hacía alguna referencia a las correrías de Basset, quien había desplegado una gran actividad en Altea, redactando cartas para distintos lugares del Reino, pero Cerdá consideraba que muy probablemente se habría embarcado de nuevo en la Armada aliada ${ }^{23}$.

Todavía fue mayor la responsabilidad otorgada a Vicente Falcó por su experiencia militar. Falcó había servido en el Tercio de Infantería Española de Tomás Arias Pacheco entre 1677 y 1680 , y pasó a Valencia para cubrir las sustituciones de teniente de gobernador y baile general. En 1692, atendiendo a su curriculum militar, Castelrodrigo le encargó la visita de las costas de poniente del Reino con el propósito de mejorar las fortificaciones, especialmente el nuevo recinto exterior que de orden del virrey se había iniciado en Alicante tras el bombardeo de la plaza por la escuadra francesa en julio de 1691, especialmente el nuevo baluarte de San Carlos para la defensa del arrabal de San Francisco ${ }^{24}$. En mayo de 1699 fue encargado por Carlos II de la administración de la Real Hacienda en la ciudad de Alicante, y en 1700 el presidente del Consejo de Castilla, Manuel Arias Porres, y el corregidor de Madrid, Francisco Ronquillo, lo comisionaron para que organizase la remisión a Madrid del grano desembarcado en Alicante para socorro de la Corte. En septiembre de 1700 Falcó fue nombrado gobernador de Orihuela y, pese a que el cargo tenía una duración trienal, le fue renovado el 10 de octubre de 1703 , y continuó hasta el 27 de noviembre de 1705 en que, atendiendo a su delicada salud, se le dio plaza de capa y espada en la Audiencia de Valencia. Durante su mandato las costas de su gobernación fueron visitadas por la Armada aliada en 1703, 1704 y 1705, y el propio Falcó describió en un largo memorial todos los avatares vividos en ese trienio: en 1703 tuvo noticia por Vicente Tous, castellano del castillo de Altea, «de que la Armada enemiga ancoraba con intención de hacer aguada en aquel río, y que se hallaba sin pólvora para oponerse a sus designios; le socorrió desde luego con cuanto le pidió»». En 1704, pudo conocer, por unos desertores, que la Armada angloholandesa se dirigía a Barcelona, por lo que «dispuso el aviso de todo a D. Francisco Velasco, Virrey y Capitán General de aquel Principado», e igualmente pudo informar al conde de Tolosa, gracias a los datos que le suministraron cuatro desertores ingleses, de las acciones que preparaba la flota aliada sobre Ceuta y Málaga ${ }^{25}$, «y con su relación se logró, no sólo la noticia cierta de las ideas de los enemigos y calidad de su armamento, sino también la resolución del combate que se vio en las costas de África, sobre Málaga». En ese año

22. A. H. N. Consejos, Leg. 18.438 Damián Cerdá al Virrey de Valencia, Altea 28 de mayo de 1704.

23. Casiano Infante confesó en su interrogatorio que Baset portaba una agenda con multitud de nombres anotados, pudiendo observar entre ellos el de D. Jacinto Forner, lo que sorprendió al interrogador, Damián Cerdá, quien escribió «que siendo de Alicante lo conozco, pero no comprendo tenga mácula, ni me persuado pueda faltar a sus obligaciones», en A. H. N. Consejos, Leg. 18.438 Damián Cerdá al Virrey de Valencia, Altea 28 de mayo de 1704.

24. Pablo Rosser Limiñana: Origen y evolución de las murallas de Alicante, Alicante 1990, pp. 101- 116.

25. Teodosio VARGAS-MACHUCA y José Antonio RuIZ; «Consecuencias de la Guerra de Sucesión en Ceuta», en La Guerra de Sucesión en España y América, Sevilla 2001, pp. 183-204, y Vicente BACALLAR: Comentarios de la Guerra de España, Madrid 1957, pp. 74-75. 
de 1704 desembarcaron en Alicante unos 100 irlandeses que se dirigían a combatir a Portugal enviados por Luis XIV, y que por falta de medios el gobernador tuvo que proporcionarles víveres para que pudieran proseguir viaje. Desde Alicante Falcó remitió munición y pólvora a Cádiz, Málaga y Gibraltar, y procuró mantener en condiciones de combate a la exigua milicia local que debía defender la plaza ante un posible ataque anglo-holandés. El 10 de agosto de 1705 , según su testimonio ${ }^{26}$, «ancoraron en aquella Playa seis bajeles a vista de las Armadas de Inglaterra y Holanda, y desembarcado un cabo solicitó, por el medio de unos pliegos del Archiduque de Austria, que diese la obediencia, y en medio de hallarse sin prevención y sin Milicia, se portó tan valeroso que no quiso recibirles, sin dar otro contento que el de la prontitud de derramar toda su sangre en defensa de la Plaza que V. M. le había encargado. Otro pliego llegó a sus manos, que dijeron ser del Príncipe de D'Armstad, y sin abrirle, no menos animoso, se pasó a las del Marqués de Villagarcía para que le dirigiese a las de V. M.» ${ }^{27}$. Tras la toma de Denia y la sublevación de la comarca de La Marina, el gobernador Falcó puso todo su esfuerzo en evitar la caída de Alicante y la sublevación en la Vega Baja de Orihuela, hasta que el 20 de noviembre de 1705 se trasladó a Valencia para tomar posesión de la plaza de consejero de capa y espada de la Audiencia, para la que había sido nombrado el 20 de junio.

La procedencia social de los magistrados, y sus vínculos familiares, les hacían consustancialmente enemigos de un movimiento que respondía «al descaro plebeyo», y a «la hez de la población», como denunciaba José Manuel Miñana ${ }^{28}$. Antes de llegar a la regencia de la Audiencia en 1705, José García Azor había obtenido la pavordía secundaria de leyes en 1680, era arcediano de Alpuente, en la diócesis de Segorbe, y vicario general del arzobispado de Valencia ${ }^{29}$. Pedro José Borrull fue catedrático de Código e Instituta de la Universidad de Valencia entre 1669 y $1685^{30}$. Bruno Salcedo había tenido a su cargo la visita de la Acequia Real de Alcira y el Real Derecho de Amortización, y era caballero de la orden de Montesa y señor de la baronía de Pamís, en Ondara, lo que en su opinión fue causa de ser su casa «blanco de las iras de Basset». Su hermano Antonio, también caballero de Montesa, se encontraba en Pamís cuando la baronía fue saqueada por los campesinos austracistas: «no sólo saquearon el referido lugar y

26. A. H. N. Consejos Leg. 18.450 Memorial de D. Vicente Falcó Blanes de Belaochaga.

27. Las crónicas borbónicas subrayaron este gesto de fidelidad, y la carta remitida a la ciudad por Felipe $\mathrm{V}$ el 28 de agosto de 1705, donde afirmaba «tendré presente estos obsequios para favoreceros y honraros». Reproducida en la crónica del jesuita Juan Bautista MALTES: Ilice ilustrada. Historia de la muy noble, leal y fidelisima ciudad de Alicante, edición de Ma Luisa Cabanes, Alicante 1991, ff. 391-391v. Una referencia a este suceso en Joaquim E. LÓPEZ I CAMPS: «La invasió austracista del Regne de Valencia (1701-1705)», en Afers 52 (2005), pp. 521-540.

28. José Manuel MiÑanA: La Guerra de Sucesión en Valencia. De bello rustico valentino, Edición de F. J. Pérez i Durá y J. Ma Estellés y González, Valencia 1985, pp. 36 y 43.

29. Jon ArRieta Alberdi: El Consejo Supremo de la Corona de Aragón (1494-1707), Zaragoza 1994, p. 606.

30. Amparo FELIPO ORTS: La Universidad de Valencia durante el siglo XVII (1611-1707), Valencia 1991, p. 310 . 
casa del suplicante, sino es que absolutamente le quemaron la almazara donde se hace el aceite que valía dos mil ducados de plata, y le destruyeron y robaron su hacienda y cosecha de diversos frutos que importaba más de 3.500 pesos. Y habiéndose retirado a Valencia le tuvieron arrestado y en gravísimo peligro de perder la vida a su rigor y violencia hasta que pudo lograr pasaporte del supuesto virrey conde de Cardona, ejecutando, por mantener la debida lealtad a V. M., el viaje a pie, enfermo, con riesgo continuado de los miqueletes hasta la villa de Requena, donde estuvo cuarenta días sumamente agravado de sus achaques por los accidentes padecidos. Y después pasó a esta Corte, en que ha permanecido cerca de un año con los trabajos y estrechez que se deja considerar ${ }^{31}$. En compensación por sus pérdidas solicitó, una vez recuperada Valencia, las propiedades que en la Huerta poseía José Vicente Torres Eiximeno, secretario de la ciudad durante el período austracista, ennoblecido por el Archiduque en 1706, del que Castellví decía que era «hombre popular, y de gran consideración en la plebe» ${ }^{32}$, y que en el exilio vienés llegó a secretario del Real Sello del Consejo de España ${ }^{33}$, después de pasar por las cárceles de Pamplona y el Alcázar de Segovia ${ }^{34}$. También era caballero de Montesa el alcoyano Francisco Descals, cuyo padre, Gaspar Descals, fue diputado en Valencia de los caballeros de la orden entre 1677 y 1679 , mientras que su hermano José Descals era caballero de Santiago desde 1687 y fiscal del Consejo de Cruzada desde $1700^{35}$. Francisco Descals se hallaba casado con la valenciana Dorotea Pérez Alós, hija del jurado de Xérica Antonio Pérez, cuyos bienes fueron confiscados por los austracistas $^{36}$. Tanto Salcedo como Descals eran asesores del lugarteniente de Montesa, pues, como ha señalado Teresa Canet, «estos togados intervendrán en las funciones administrativas de Montesa precisamente en virtud de su adscripción a la Audiencia. Y, de hecho, Montesa no contaba con letrados propios, sino con los mismos del tribunal regio $\rangle^{37}$. Ambos, Descals y Salcedo, estaban emparentados, pues Francisco Descals era sobrino de los también magistrados Diego y José Descals y Salcedo, magistrados de la Audiencia foral fallecidos en 1687 y $1672^{38}$. También era Descals por ascendiente materno el magistrado Pedro Mayor. Estudiante en Salamanca, como los letrados de su familia, Mayor Descals fue catedrático en la Universidad de Valencia desde 1685 hasta 1701. Estaba emparentado por matrimonio con Luisa Ruiz Lihory con los Ruiz Lihory Rocafull, cuyos hermanos pertenecían a la pequeña nobleza valenciana. José era titular

31. A. H. N. Consejos Leg. 18.476 Memorial de D. Antonio Salcedo Vives.

32. Francisco de CASTellvi: Op. Cit. vol. I, p. 517, y Carmen PéreZ APARIClo: «Cambio dinástico y disidencia política en el País Valenciano», en Eliseo Serrano (ed.): Felipe V y su tiempo, Zaragoza 2004, vol. II, pp. 119-149. La referencia a Torres Eiximeno en p. 145.

33. Agustí AlCOBERRo: Op. Cit. p. 53 y Virginia LeÓN: Carlos VI...p. 270.

34. La renta anual de los bienes confiscados a José Vicente Torres se estimaron en 1713 en 409 Libras 1 sueldo y 10 dineros, en Henry Kamen: Op. Cit. p. 354.

35. A. G. S. Gracia y Justicia Lib. 1.560 Fiscalia del Consejo de Cruzada a D. José Descals.

36. Carmen PÉREZ APARICIO: «La política de represalias...», p. 167.

37. Teresa CANET APARISI: La Audiencia valenciana en la época foral moderna, Valencia 1986, p. 170.

38. Sobre la famila Descals, vid. Teresa CANET APARISI: La magistratura...pp. 259-262. 
de los señoríos de Alfarrasí, Mosquera y Llosa, y Pedro era barón de Alcalalí, y todos ellos salieron de Valencia tras ver sus bienes confiscados por las autoridades austracistas. Francisco Despuig y Mercader era cuñado de Juan de la Torre y Orumbella, magistrado de la Audiencia foral entre 1678 y 1793, de la que fue regente, y Consejero de Aragón, del que fue destituido por no abandonar Madrid durante la primera ocupación de la capital por el Archiduque ${ }^{39}$, pariente del conde de Albalat, y tío de José de la Torrre Despuig, caballero de Montesa, oidor de la Chancillería de Valladolid, alcalde de Casa y Corte y fiscal del Consejo de Cruzada. Vicente Falcó estaba emparentado con Félix Falcó, barón de Benifayó, justicia y jurado de la ciudad de Valencia en diversas ocasiones durante el reinado de Carlos $\mathrm{II}^{40}$, desinsaculado en 1706 por su felipis$\mathrm{mo}^{41}$, y designado regidor noble en el primer ayuntamiento borbónico ${ }^{42}$. El alicantino Pedro Burgunyo pertenecía a una familia que había desempeñado ininterrumpidamente cargos en el municipio alicantino desde $1372^{43}$, y su hermano Pedro sería designado Regidor decano en el ayuntamiento borbónico constituido en 1709, tras la toma de la ciudad por D'Asfeld ${ }^{44}$, y Damián Cerdá también tenía parientes en ese primer ayuntamiento alicantino al ser cuñado suyo el regidor Francisco Colomina ${ }^{45}$, hermano de su mujer Antonia Colomina.

Especial relevancia familiar tenían los hermanos Montserrat Crespi de Valldaura. Tanto Andrés como Vicente pertenecían a un linaje que, como no cesaban de recordar, servía al rey «más de siete siglos», y que decían tenía su origen en Ponce de Guardia, enviado por el rey de Francia en el año 985 para ayudar al conde de Barcelona Ramón Borrell en su lucha contra los musulmanes, y que al conquistar el castillo de Montserrat heredó ese apellido. Los Crespí de Valldaura estaban emparentados con el conde de Sumacárcer, reputado borbónico durante el conflicto sucesorio, y durante el siglo XVII Cristóbal Crespí había sido magistrado de la Audiencia entre 1631 y 1635 antes de llegar a ser vicecanciller de la Corona de Aragón en 1652, y Pedro Montserrat había ejercido como oidor de causas criminales y civiles desde 1669 hasta su muerte en 1678. Como ha señalado Teresa Canet, «en Vicente y Andrés Montserrat Crespí de Valldaura confluía una doble tendencia de tradición familiar de servicio, ya que tanto entre sus ascendientes maternos como entre los paternos la inclinación a la toga era un hecho» ${ }^{46}$. Además Andrés Montserrat estaba casado con Ángela de Palafox y Marcilla, hija de Vicenta Crespí de Valldaura, cuyo padre era el conde de Sumacárcer y Cirat, además de estar emparentada con el marqueses de Ariza y de Lazán, con la condesa de Cervelló y

39. Jon ARrieta Alberdi: Op. Cit. p. 627.

40. Pablo Pérez Garcia: El Justicia Criminal de Valencia (1479-1707), Valencia 1991, p. 445.

41. Amparo FELLiPO ORTS: Insaculación y élites de poder en la ciudad de Valencia, Valencia 1996, p. 80.

42. A. H. N. Consejos Lib. 2.494 ff. 46v-47 Real Cédula, Madrid 13 de diciembre de 1707.

43. Sobre la familia Burgunyo, vid. Verónica MATEO RIPOLL: Oligarquia y poder en el siglo XVIII. La familia Burgunyo de Alicante, Alicante 1994.

44. A. H. N. Consejos Lib. 2.494 f. 28 lv Real Cédula, 23 de febrero de 1709.

45. A. H. N. Consejos Lib. 2.494 f. 282 v Real Cédula, 23 de febrero de 1709.

46. Teresa CANET APARISI: La magistratura...pp. 257-259. la cita en p. 258. 
Buñol, y con el conde de Montoro, mientras que su hermano Vicente, colegial mayor en el Arzobispo de Salamanca, era caballero de Montesa, bailío de Sueca y estaba casado con María Vicente Cruilles.

Estos perfiles aristocráticos, reforzados por lazos de parentesco, de la magistratura valenciana, y su concepción de lealtad al monarca legítimo, al que se sentían unidos por juramento de fidelidad, les llevó a arrostrar la pérdida de su patrimonio y el exilio, en condiciones difíciles que cada uno de ellos relató, con mayor o menor detalle, en memoriales al rey que constituyen testimonios vivos, aunque interesados y subjetivos, de su peripecia personal y la de sus familias. Andrés Montserrat fue enviado por el virrey Villagarcía en 1703 a poner en resguardo las poblaciones costeras «de la parte de Levante» ante la presencia de la Armada enemiga en su primera incursión por el litoral valenciano. Tuvo la responsabilidad de distribuir las milicias «y las demás providencias de su defensa». Tras esa primera experiencia, en 1705 fue enviado por Villagarcía, con despacho de gobernador de Armas, «a las marinas de Altea por ser el partido más expuesto a la invasión y desembarco de los enemigos, y en ellas, y a sus expensas, se mantuvo cuatro meses», cumpliendo con tareas de observador, informando puntualmente al virrey del ataque a Denia. Al frente de las milicias que estaban a su cargo acudió a Gandía, e intentó que la sublevación no se extendiera hacia tierras de la Ribera del Xúquer, sin demasiado éxito, porque las milicias, «flacas y malhumoradas», eran inútiles para intentar cualquier acción militar. Cuando llegaron las tropas de caballería del mariscal de campo Luís de Zúñiga, con 1.800 soldados, a primeros de septiembre de 1705, todos los esfuerzos estuvieron dirigidos a evitar la extensión de la revuelta, y el oidor Montserrat colaboró en la toma del Puerto de Sagra y del cauce del río Molinell ${ }^{47}$, «arrojando y deshaciendo el cuerpo de sediciosos que le ocupaban». No obstante, el problema de las milicias que comandaba Montserrat parecía no tener solución, pues fracasó en los intentos de recomponer aquellas compañías que habían desertado. La llegada el 9 de septiembre del teniente general José de Salazar abrió una esperanza en el magistrado Montserrat y en el propio virrey, para quien «con él mudará semblante la temeridad de los sediciosos»» ${ }^{48}$. En su reseña de aquellos días, Andrés Montserrat menciona su intervención en el frustrado ataque a Denia del 11 de septiembre, en que incendiaron el arrabal de la ciudad un día antes de que Salazar y Zúñiga abandonaran territorio valenciano con destino a Cataluña, verdadera prioridad desde el desembarco aliado en las cercanías de Barcelona. Decía Montserrat: «pasaron a Denia a incendiar sus arrabales, en cuyas diligencias, como en las demás que motivaron las turbaciones del Reino, llevé la mayor parte del trabajo, y fue tan excesivo que quebrantó gravemente mi salud». Probablemente, la falta de combatividad de sus cada vez más menguadas milicias fue determinante en la postración del magistrado. Según el testimonio de Zúñiga un día después del postrer ataque a Denia, «las milicias, así de caballería como de infantería, no valen cosa ninguna, ni se puede fiar de ellos

47. Sobre ese suceso, vid. José Luis CERVERA TORREJÓN: Basset: mite i realitat de / heroi valencià, Valencia 2003, pp. 85-86.

48. A. H. N. Leg. Consejos 18.743 Villagarcia a Grimaldo, Valencia 7 de septiembre de 1705. 
cosa ninguna $\rangle^{49}$. Cuando cayó Valencia Andrés Montserrat, todavía convaleciente, dejó la ciudad, dejando a su madre, mujer e hijos en un convento, y sus propiedades fueron confiscadas por las nuevas autoridades. Acudió a Requena, siguiendo instrucciones del presidente del Consejo de Aragón para ponerse a las órdenes del nuevo virrey, el duque de Arcos, designado para ese cargo en noviembre de 1705: «por mantener la debida lealtad y amor al real servicio de V. M., se salió luego de la ciudad, abandonando madre, mujer e hijos y todo el caudal de sus mayorazgos, y acudiendo a la villa de Requena, señalada Plaza de Armas, pudo entender por diferentes cartas del presidente, conde de Frigiliana, le había sido a V. M. agradable este real servicio, y que igualmente lo sería permanecer el suplicante en aquella plaza para asistir a su comandante, y al virrey duque de Arcos, como lo hizo a todas horas, bajando al campo y a otros lugares del Reino, manteniéndose en la frontera hasta que el conde las Torres volvió a estos parajes con las tropas $\rangle^{50}$.

También acudió a Requena, tras vagar por La Mancha, Pedro Doménech, «padeciendo en su adelantada edad y pocos haberes contratiempos y trabajos $\rangle^{51}$. Bruno Salcedo Vives narró el saqueo de su casa en Valencia por Basset, utilizando el pretexto «de sacar de ella parte del equipaje del regimiento del marqués de Pozoblanco, poniendo al suplicante en paraje de perder la vida el accidente que le ocasionó tal rigor, y sin embargo de esto le puso en riguroso arresto, y confiscó sus bienes, sin haber obtenido más descanso en tantos trabajos que el permiso de salir de dicha ciudad», acompañado de sus tres hijos varones, pues su mujer y dos hijas quedaron confinadas en un convento de Valencia, «sin más asistencia para mantenerse que la piedad de las religiosas por el embargo de todos sus bienes $\rangle^{52}$. Francisco Despuig estaba enfermo en cama cuando cayó Valencia, «y mal convalecido salió fugitivo de aquella ciudad, abandonando su patrimonio y casa, que después saquearon los sediciosos y rebeldes». Pasó a Yeste, durante un breve período, antes de dejar definitivamente territorio valenciano y refugiarse en Madrid ${ }^{53}$. Vicente Falcó, hasta su llegada a Madrid, «pasó los las amarguras de innumerables trabajos, y aún desprecios», acompañado de toda su familia ${ }^{54}$.

El estado en que llegaron a la Corte los magistrados valencianos era penoso. Bruno Salcedo llegó a Madrid con sus hijos varones, «menos el mayor, que siendo capaz de tomar las armas sigue las tropas de V. M. sirviendo en el regimiento del marqués de Pozoblanco», y su hermano Antonio. El 18 de enero de 1707 fue nombrado regente de la Audiencia que debía reunirse en Orihuela, ocupada ya por las tropas del obispo Luis Belluga ${ }^{55}$. Vivía de limosna, «pues saqueada su casa y ocupado su patrimonio del

49. A. H. N. Consejos Leg. 18.743 Zíñiga a Villagarcía, Campo de Denia 12 de septiembre de 1705.

50. A. H. N. Consejos Leg. 18.476 Memorial de D. Andrés Montserrat Crespi de Valldaura.

51. A. H. N. Consejos Leg. 18.476 Memorial de D. Pedro Doménech.

52. A. H. N. Consejos Leg. 18.476 Memorial de D. Bruno Salcedo Vives.

53. A. H. N. Consejos Leg. 18.476 Memorial de D. Francisco Despuig Mercader.

54. A. H. N. Consejos Leg. 18.450 Memorial de D. Vicente Falcó y Blanes

55. Pere Molas RibalTa: La Audiencia borbónica del Reino de Valencia, 1707-1834, Alicante 1999, p. 22 
enemigo le faltan todos los efectos para dicha satisfacción», en referencia al pago de la medianata por el nuevo cargo, que le resultaba imposible abonar. Por eso solicitaba se le hiciera gracia de ese derecho ${ }^{56}$. Los hermanos Montserrat llegaron a las proximidades de Madrid a fines de junio de 1706, cuando la capital había sido tomada por el ejército austracista, "por lo que fue preciso quedarse en Getafe» y fueron hechos prisioneros, y liberados por las tropas de Antonio del Valle cuando se produjo la retirada del Archiduque. Este contratiempo les fue muy gravoso a los Montserrat, «por haberle obligado a malvender lo poco que les quedaba, después de un año de peregrinación, con tan graves calamidades que sólo podían encontrar alivio en la real presencia y servicio de V. M.». Cuando llevaba Andrés Montserrat 16 meses de exilio, con su mujer y dos de sus hijos, la situación era, en su narración, desesperada: «no restándole nada que vender, ni encontrando persona que le quiera suministrar los precisos alimentos que para la manutención de su numerosa familia $\rangle^{57}$, y solicitaba un socorro por vía de limosna o a cuenta de los devengados que se le debían de su sueldo. El 14 de abril de 1707 el Consejo de Aragón propuso socorrer a los hermanos Montserrat con $3.800 \mathrm{rls}$. a cada uno «para que no lleguen a morir de hambre y experimenten en algún modo los efectos de su real conmiseración, en atención a lo que han padecido y perdido ${ }^{58}$, la misma cantidad que recibieron el resto de los magistrados.

La muerte le llegó a Pedro Mayor en su exilio madrileño, falleciendo en el Hospital de Aragón, dejando a la viuda, Luisa Ruiz Lihory, con dos hijos «de tierna edad, que el mayor aún no tiene cuatro años», y sin ingresos ni patrimonio. Sólo pudo sobrevivir «porque la suplicante es una mujer noble» y recibía ayuda de parientes y allegados, aunque con dificultades. En junio de 1707 suplicó participar en el reparto de los 3.800 rls. que habían recibido el resto de los magistrados, y «situar unos alimentos para la suplicante y sus pobres hijos, para que consiga verles en edad que, imitando a su padre, puedan sacrificarse al real servicio de V. M. y conseguir la gloria de morir en él $\rangle^{59}$.

La recuperación de Valencia dio lugar a nuevos memoriales en los que los magistrados solicitaban ser premiados por sus penalidades en la hora del triunfo. El regente García Azor fue nombrado Consejero de Aragón en sustitución del austracista De la Torre Orumbella. Con la disolución del Consejo el 15 de julio de 1707 fue nombrado para el Consejo de Hacienda, pero no llegó a tomar posesión porque el 26 de julio pasó a ocupar plaza en el Consejo de Castilla ${ }^{60}$. Una trayectoria similar siguió Pedro José Borrull, llamado por Miñana "eximio jurisconsulto» ${ }^{61}$ por ser autor de diversos textos sobre derecho foral ${ }^{62}$ y contar con la amistad del deán de Alicante, Manuel Martí ${ }^{63}$.

56. A. H. N. Consejos Leg. 18.476 Memorial de D. Bruno Salcedo Vives.

57. A. H. N. Consejos Leg. 18.450 Memorial de D. Andrés Montserrat Crespi de Valldaura.

58. A. H. N. Consejos Leg. 18.450 Consulta del Consejo de Aragón, Madrid 14 de abril de 1707.

59. A. H. N. Consejos Leg. 18,450 Memorial de Da Luisa Ruiz de Lihory.

60. Janine FAYARD: Los miembros del Consejo de Castilla (1621-1746), Madrid 1982, p. 512.

61. José Manuel MiÑana: Op. Cit. p. 64.

62. Pere Molas: La Audiencia...p. 75.

63. Antonio Mestre: Manuel Martí, el Deán de Alicante, Alicante 2003, p. 88. 
Borrull sustituyó al austracista catalán José Rull, destituido en octubre de 1706, y el 26 de julio de 1707 pasó al Consejo de Castilla como fiscal ${ }^{64}$, falleciendo un año después. Su esposa, María Bernarda Ramón, presentó un memorial solicitando al monarca una limosna por haber quedado en la mayor pobreza y con siete hijos a su cargo, aduciendo los servicios prestados por su marido y las penalidades de su exilio. Se le concedieron 300 ducados anuales sobre las rentas reales de Valencia. Tuvo problemas para hacer efectiva esa ayuda, y la Cámara de Casatilla, en consulta de 12 de febrero de 1710, consideraba muy escaso ese auxilio «por lo que sólo corresponde a poco más de real al día a cada persona, cantidad tan módica que no alcanzará para su preciso sustento», y recordaba «los especiales méritos y servicios» de su marido ${ }^{65}$.

También Vicente Montserrat fue nombrado, en primera instancia, fiscal del Consejo de Aragón, para pasar el 20 de julio de 1707 al Consejo de Órdenes, donde permaneció hasta su fallecimiento el 20 de enero de $1738^{\circ 6}$. Si bien fue nombrado el 9 de enero de 1716, junto a José Rodrigo, protector del Hospital de Nuestra Señora de Montserrat en la Corte ${ }^{67}$, no parece que el Consejo de Órdenes fuera premio que compensara sus sacrificios durante la Guerra. Entre 1720 y 1728 Vicente Montserrat pretendió en siete ocasiones plaza en el Consejo de Castilla, en las vacantes que se producían en el Supremo Tribunal por el fallecimiento de los consejeros Mateo Pérez Galeote, Pedro Afán de Ribera, Francisco Ametller, Cándido de Molina y Francisco Velázquez Zapata. En su pretensión siempre adujo, sin éxito, que «abandonó su casa y plaza en las turbaciones de Valencia ${ }^{68}$. Bruno Salcedo, todavía en el exilio madrileño, solicitó en noviembre de 1706 una fiscalía en el Consejo de Aragón, y a poco la plaza dejada vacante en el Consejo de Hacienda por fallecimiento del catalán borbónico José Güell ${ }^{69}$. Sin embargo, el 28 de junio de 1707 fue nombrado alcalde de Casa y Corte, y el 10 de noviembre de 1713 logró alcanzar plaza en el Consejo de Castilla ${ }^{70}$, que disfrutaría hasta su fallecimiento el 19 de febrero de $1725^{71}$. Francisco Descals sería premiado con una plaza de oidor en la Chancillería de Valladolid, que pasó a servir el 12 de agosto de 1707, y que no abandonaría hasta su muerte en 1720. En diciembre de 1707 Vicente Falcó salió de Madrid para tomar posesión como corregidor de Burgos ${ }^{72}$, donde falleció en 1710 .

64. Santos Corona GONZALEZ: Ilustración y Derecho: los fiscales del Consejo de Castilla en el siglo XVIII, Madrid 1992, p. 44.

65. A. H. N. Consejos Lib. 1.911, ff. 121-122 Consulta de la Cámara de Castilla, Madrid 12 de febrero de 1710.

66. Gaceta de Madrid, 4 de febrero de 1738.

67. A. H. N. Consejos Lib. 1.917, ff. 231-233, Consulta de la Cámara de Castilla, 2227 de mayo de 1716.

68. Ver las consultas en A. G. S. Gracia y Justicia Legs. 135, 138, 139 y 140

69. A. H. N. Consejos Leg. 18.476 Memoriales de D. Bruno Salcedo Vives.

70. Janine FAYARD: Los ministros del Consejo Real de Castilla (1621-1788), Madrid 1982, p. 123, y Gaceta de Madrid 14 de noviembre de 1713.

71. Gaceta de Madrid 20 de marzo de 1725.

72. A. G. S. Gracia y Justicia Lib. 1.561. 
Sólo cuatro de los doce magistrados que salieron de Valencia tras la caída de la ciudad en manos austracistas, ocuparon plaza en la nueva Chancillería nacida del decreto de Nueva Planta de junio de 1707. Pedro Doménech fue oidor, nombrado el 30 de mayo de $1707^{73}$, y en ese puesto permaneció hasta su fallecimiento en 1714 . Francisco Despuig se incorporó a la nueva Chancillería como alcalde del crimen en agosto de 1707, y en 1713 fue propuesto por Melchor de Macanaz para abogado real en la sala de Alcaldes de Casa y Corte, y también para magistrado de la Chancillería granadina en atención a que era "caballero y gran letrado», pero sobre todo por no considerar conveniente que continuase ejerciendo en el tribunal de Valencia «por ser valenciano ${ }^{74}$. Sin embargo Despuig no abandonó tierras valencianas, y ascendió a oidor de la Audiencia a primeros de $1715^{75}$, y en ese puesto se mantuvo hasta su fallecimiento el 21 de noviembre de 1740. Juan Burgunyo y Damián Cerdá ocuparon sendas fiscalías. Ambos habían sido nombrados para actuar como jueces de confiscaciones en Orihuela y Elche antes de la batalla de Almansa. Burgunyo sería ascendido a oidor del tribunal valenciano en 1709, y en 1713 se trasladó a Madrid como alcalde de Casa y Corte ${ }^{76}$. Intentó en 1715 llegar a consejero de Indias, apoyado por el consejero de Castilla Juan Milán de Aragón, quien recordó como mérito sobresaliente que «en su antigua Real Audiencia tuvo plaza de abogado patrimonial, la cual sirvió desde el año 1702 hasta que se perdió aquella ciudad, y por no mantenerse con los enemigos se vino a la Corte» ${ }^{77}$. Cerdá fue primero fiscal criminal de la nueva Chancillería, y en 1711 pasó a desempeñar la fiscalía civil por ascenso de Francisco Velázquez a alcalde de Casa y Corte. Otro fallecimiento, el del oidor Isidro San Pedro, le permitió ascender a ese puesto en 1713, ya en la reconvertida Audiencia. Damián Cerdá falleció en Moncada en $1725^{78}$.

Aunque no como magistrado, Andrés Montserrat quedó vinculado a la nueva Chancillería desde el 3 de septiembre de 1707 aunque su pretensión, elevada al monarca en diciembre de 1706, era obtener el título de marqués de la Corona de Aragón ${ }^{79}$, pero tan sólo logró el cargo de alguacil mayor de la Chancillería, que desempeñó hasta

73. A. H. N. Consejos Leg. 17.984 Decreto nombrando Oidor de la Chancillería de Valencia a D. Pedro Domench, 30 de mayo de 1707.

74. A. G. S. Gracia y Justicia Leg. 133 Melchor de Macanaz propone sujetos para plazas vacantes en Consejos y Chancillerias.

75. Gaceta de Madrid 18 de diciembre de 1714.

76. Gaceta de Madrid 14 de noviembre de 1713.

77. A. G. S. Gracia y Justicia Leg. 133 Sujetos propuestos para plaza togada del Consejo de Indias. EI informe reservado de Milán de Aragón lleva fecha de 22 de febrero de 1715.

78. Sobre Cerdá, vid. Pere MOLAs Ribalta: «Las Audiencias de la Corona de Aragón», en Estudis 5 (1976), pp. 115,120 y 121.

79. A. H. N. Consejos Leg. 18.476 Memorial de D. Andrés Montserrat Crespi de Valldaura. 
que fue nombrado lugarteniente general de la orden de Montesa en 171 $7^{80}$, si bien obtuvo la gracia de que el alguacilazgo pasase a su hijo Vicente Montserrat y Palafox ${ }^{81}$.

Otros hijos y descendientes también se beneficiaron de la lealtad y servicios de los magistrados que dejaron Valencia en 1705. Vicente Borrull Ramón, hijo de Pedro José Borrull, fue alcalde del crimen de la Audiencia de Valencia desde 1735 hasta 1741, y oidor de la misma Audiencia desde 1741 hasta 1751, cuando falleció, y siempre adujo como mérito la lealtad de su padre. Otro hijo, José, fue catedrático de la Universidad de Salamanca y fiscal del Consejo de Indias, y su hermano Francisco fue canónigo de Valencia, auditor de la Rota y obispo de Tortosa entre septiembre de 1757 y agosto de 1758 , en que murió ${ }^{82}$. Uno de sus nietos, hijo de Vicente, fue Francisco Javier Borrull y Vilanova, catedrático de Instituta de la Universidad de Valencia desde 1774 hasta $1778^{83}$, y diputado por Valencia en las Cortes de Cádiz, donde defendió la Inquisición, ya que era familiar del Santo Oficio, y el absolutismo ${ }^{84}$. Un hijo de Vicente Montserrat fue Joaquín Montserrat Cruilles, militar ennoblecido por sus servicios en la conquista de Nápoles y Sicilia con el marquesado de Cruilles, y que llegaría a virrey de México en 1760 y a teniente general. De los cinco hijos varones de Bruno Salcedo, dos de ellos, Bruno y Marcos fueron respectivamente monjes bernardo y dominico ${ }^{85}$. José, que acompañó a su padre en el exilio madrileño, fue caballero de Montesa, comendador de Burriana, sargento mayor de Valencia y regidor de la ciudad desde 1715 , con escasa asistencia al consistorio $^{86}$, y del que se afirmaba que no tenía «inclinación a este oficio ${ }^{87}$. Un cuarto hijo, Francisco, estaba casado con Teresa Mateu, hija de Domingo Mateu y Silva, que fue regente de la Audiencia foral entre 1693 y su fallecimiento en 1700 . Francisco Salcedo alcanzó la alcaldía del crimen de la Audiencia de Valencia «por los servicios de su padre D. Bruno que murió consejero de Castilla», según señalaba en su informe reservado el consejero Juan Valcárcel Dato ${ }^{88}$. Por último, Bernardino Salcedo también fue alcalde del

80. Creado en 1593, el lugarteniente tiene a su cargo «muy amplias funciones, tanto gubernativas como contenciosas». Felipe V lo confirmó el 14 de mayo de 1712, en Fernando ANDRES ROBRES: «Los decretos de «nueva planta» y el gobierno de la Orden de Montesa», en Antiguo Régimen y liberalismo. Homenaje a Miguel Artola, vol. 3, Madrid 1995, pp. 37-47.

81. Pere Molas Ribalta: La Audiencia...pp. 100-101.

82. Maximiliano Barrio Gozalo: El Real Patronato y los obispo españoles del Antiguo Régimen (15561834), p. 453.

83. Donó su biblioteca a la Universidad, en Salvador AlBIÑANA: Universidad e Ilustración. Valencia en la época de Carlos III, Valencia 1988, p. 139.

84. Emilio LA PARRA LÓPEZ: El primer liberalismo y la Iglesia, Alicante 1985, pp. 204-207, y Alberto GIL Novales: Diccionario biográfico del Trienio Libeal, Madrid 1991, p. 96.

85. Janine FAYARD: Los miembros...p. 306.

86. María del Carmen IRLES VICENTE: El régimen municipal valenciano en el siglo XVIII. Estudio institucional, Alicante 1995, pp. 191-192.

87. Encarnación GARCIA MONERRIS: La monarquia absoluta y el municipio borbónico. La reorganización de la oligarquia urbana en el Ayuntamiento de Valencia (1707-1800), Madrid 1991, p. 114.

88. A. G. S. Gracia y Justicia Leg. 140 Informe de Juan Valcárcel Dato para la provisión de la Alcaldia del Crimen de la Audiencia de Valencia, 29 de diciembre de 1728. 
crimen en Valencia desde 1717 en consideración a los servicios de su padre y a la fidelidad mostrada por la familia a Felipe V, pues Milán de Aragón, en su informe destacaba que era «hijo de Bruno de Salcedo, ministro del Consejo, y que imitando a su padre en la fidelidad, vino en su compañía a esta Corte el año 1706 cuando los enemigos entraron en Valencia ${ }^{89}$.

\section{LA NOBLEZA TITULADA}

El mismo deseo de estabilidad y sentimientos de fidelidad y servicio del que hizo gala el bloque burocrático, mostró una parte mayoritaria de la nobleza valenciana, y a ello habría que añadir el acusado temor a la agitación social alentada por las promesas antiseñoriales de Basset ${ }^{90}$. Con la excepción de los condes de Cardona, Elda, Cirat, y los marqueses de Boil, Rafal y de la Casta, el resto de los títulos valencianos abandonaron el Reino tras el triunfo austracista. En la relación del Consejo de Aragón de 9 de noviembre de 1706 figuraban, bajo el epígrafe Títulos de Valencia, la condesa de Castrillo, los condes de Parcent, del Real, Villanueva, Castellar, Carlet y Sumacárcer, la marquesa de Bélgida, y los marqueses de Albaida y de la Escala. Habría que añadir los nombres del conde de Cervelló y el marqués del Bosch, que figuraban como Gobernadores de Valencia y Alicante, y la condesa de Buñol que, como suegra del conde de Cervelló, venía consignada entre los miembros de la familia que acompañaron a éste al exilio, el marqués de Malferit, incluido en la relación de caballeros de Xátiva, y el de Rafol, que figuraba entre los caballeros originarios de diferentes lugares del Reino.

Otros titulados, de la más linajuda aristocracia castellana, vieron sus bienes valencianos confíscados. Al duque del Infantado le secuestraron la villa de Alberic, y los lugares de Alcocer, Gavarda y Ayora ${ }^{91}$. El de Arcos, marqués de Elche, perdió momentáneamente las villas de Elche, Crevillente, Aspe, y los lugares de Patraix y Planes, y el de Gandía, Pascual Francisco de Borja Carroz, sus numerosos estados como conde de Oliva y Villalonga, y marqués de Llombai. El duque de Medinaceli, Luís de la Cerda y Aragón, duque de Segorbe y marqués de Denia, vio secuestradas las ciudades de Denia y Segorbe, las villas de Jávea y Ondara, y numerosos lugares de señorío ${ }^{92}$. El hijo del que fuera virrey de Valencia desde 1690, marqués de Castelrodrigo, como marqués de Almonacir, vio secuestrado su señorío del mismo nombre, y el marqués de Cocentaina la villa de Cocentaina y los lugares de Penella, Alcudia, Turballos, Gayanes, Alcocer y

89. A. G. S. Gracia y Justicia Leg. 133 Informe de Juan Milán de Aragón para la provisión de la Alcaldia del Crimen de la Audiencia de Valencia, 9 de abril de 1715.

90. Sobre las motivaciones de la nobleza valenciana por una u otra opción, vid. a Juan A. CHIQUILLO PÉREZ: «La nobleza austracista en la guerra de Sucesión: algunas hipótesis sobre su participación», en Estudis 17 (1991), pp. 115-147.

91. Vicente SEGUI Roma: La Guerra de Sucesión en Ayora, Alicante 1991.

92. Vid. las jurisdicciones señoriales en Valencia en Henry Kamen: La Guerra de Sucesión en España, Barcelona 1974, pp. 436-439 y, sobre todo, en Antonio GIL OLCINA: La propiedad señorial en tierras valencianas, Valencia 1979. 
Muro. El marqués de Aitona, de linaje catalán y con una activa presencia en la Guerra de Sucesión a favor de Felipe $\mathrm{V}^{93}$, como barón de Chiva, vio su villa secuestrada, y la marquesa de Llanera y condesa de Olocau, María Sanz Vilaragut, perdió sus señoríos de Llanera, Olocau y Gátova, y todo el valle alto de Carraixet.

La participación de los nobles borbónicos valencianos en los acontecimientos de la guerra fue, salvo excepciones de algunos titulados que se mantuvieron expectantes en los primeros momentos, de colaboración con el virrey Villagarcía, aunque de eficacia dudosa. El marqués de Albaida, Ximén Pérez Milán de Aragón, estaba bien relacionado en la Corte desde que en 1690 fue embajador del reino ante Carlos II para solicitar la continuidad del conde de Altamira como virrey de Valencia ${ }^{94}$; allí recibió la merced de gentilhombre de cámara, e intervino poco después en la represión de la revuelta campesina en La Marina de 1693 «con 800 hombres pagados a sus costas», y «no se retiró a su casa hasta que desalojados quedó desvanecido aquel motín $\rangle^{95}$. Cuando se produjo la toma de Denia, su hijo, el conde de Buñol ${ }^{96}$, pasó a la comarca con una compañía de 50 infantes y otra de 30 caballos, y el marqués contribuyó con 50 doblones. Una vez perdida Valencia, el marqués de Albaida, con su mujer, Micaela Mercader, partió para Utiel, de donde se trasladó a San Clemente y, con la toma de Madrid por el Archiduque, quedó residiendo en Villarejo de Salvanés «hasta que Madrid se restituyó a la obediencia de S. M.».

El conde de Carlet, Felipe Lino Castellví, miembro de una de las grandes casas valencianas por su tradición y renta ${ }^{97}$, tuvo una posición ambigua en los primeros momentos, y en sus memoriales intentó subrayar su desprecio por las ofertas que le llegaron de las nuevas autoridades: «estando ya con las botas calzadas para ponerse a los píes de V. M. en nombre de aquellos magistrados, frustró sus designios la repentina sublevación con que se entregó a ajeno dominio, y aunque al suplicante, por su séquito, o por su notoria afición a la nación francesa, cuyos naturales, de muchos años a esta parte, tenían en su casa entrada y patrocinio, se le hicieron largas y alegres promesas; pero las abandonó con sus casas, estados y más de ochocientos mil pesos de renta, a sólo impulso de su fidelidad $»^{98}$. Cuando los austracistas le secuestraron la villa de Carlet, el lugar de Benimodo y la baronía de Tous ${ }^{99}$, dejó Valencia el 11 de enero de 1706, acompañado de su mujer y tres de sus hijos, «y pisando a cada paso un peligro,

93. Pere Molas Ribalta: «El Marquès d'Aitona a la Guerra de Successió», en Bulletí de la Societat Catalana d'Estudis Historics, XI (2000), pp. 51-59.

94. Sebastián Garcia MartíneZ: Op. Cit. pp. 242-244.

95. A. H. N. Consejos Leg. 18.476 Memorial del Marqués de Albaida.

96. El pleito por la sucesión del condado de Buñol se sustanció en la Audiencia en 1705. Los pretendientes perdedores, Galcerán Mercader Cernecio y María Cervelló fueron austracistas, en Juan A. Chrquillo PÉrez: Op. Cit. p. 134.

97. Jorge CATALÁ SANZ: Rentas y patrimonios de la nobleza valenciana en el siglo XVIII, Madrid 1995, pp. 23-25.

98. A. H. N. Consejos Leg. 18.476 Memorial del Conde de Carlet.

99. Carme PÉrez APARICIO: «La política de represalias...», p. 193. 
buscado y seguido de los enemigos, se trasladó a Castilla». Una vez dejada en Madrid su familia pasó a Aragón para luchar por recuperar Barbastro, pero tuvo que regresar de nuevo a la seguridad de Castilla.

Cristóbal Crespí de Valldaura, conde de Sumacárcer, primogénito de la condesa de Castrillo, se hallaba emparentado con la aristocracia castellana, pues en 1698 se había casado con Josefa Hurtado de Mendoza, hija de los condes de Orgaz, y heredera del título después de que su padre se pasara al austracismo, una circunstancia compartida por otros nobles valencianos, como el conde de Parcent, casado con una de las hijas de los marqueses de Santa Cruz, de la misma familia de los Hurtado de Mendoza, y también exiliados en Viena tras la contienda ${ }^{100}$. Desde los primeros instantes de la sublevación en Valencia, Sumacárcer se puso a las órdenes del virrey, y había acompañado al teniente general José de Salazar cuando este llegó en apoyo de Luis de Zúñiga en los intentos por sofocar la revuelta en la Marina. El conde dejó Valencia en marzo de 1706, acompañado de su madre, la condesa de Castrillo, su mujer y cinco hijos, arrostrando grandes dificultades pues, según su testimonio, «los enemigos le dificultaron la salida con varios pretextos, que pudo lograr fugitivo y con sólo el vestido que llevaba puesto». Se incorporó a las tropas del conde de las Torres, e intervino en los ataques a Alcira ${ }^{10 !}$ y Xátiva en la primavera de 1706, hasta la retirada del ejército borbónico de tierras valencianas, «por cuyo motivo se pasó el suplicante a la raya de Andalucía a conducir su mujer y familia, librándola de los enemigos que infestaban la Mancha» ${ }^{102}$.

El conde de Villanueva, Jerónimo Vallterra, que era caballero de Montesa y comendador de Burriana, recibió el 18 de agosto de 1705 órdenes del virrey para pasar a Denia e impedir el desembarco de las tropas, pero cuando llegó a la comarca se encontró aislado y sitiado en Xávea hasta la llegada del teniente general José Salazar. Cuando las tropas de Salazar abandonaron Valencia, Villanueva pasó a Villarreal y, posteriormente, a Cullera, intentando hacer efectivas las órdenes de sofocar la revuelta pero sin medios para cumplirlas, regresando a Valencia «un día antes de que ésta se perdiera, y solicitó el que los enemigos no la ocupasen, siendo uno de los que asistieron a la puerta de San Vicente para la defensa de aquella ciudad; pero habiéndola ocupado los enemigos pidió $\mathrm{D}$. Jerónimo pasaporte, el que le dieron cuando al virrey, y gustoso abandonó su casa, la encomienda, y cuanto tenía por no estar en otro dominio que el de V. M.». Acompañado de su mujer, «burlando las repetidas acechanzas de los miqueletes, por quienes en varias partes estaban cortados los caminos, y habiendo encaminado su viaje a Zaragoza, a donde ha sido preciso hacer alguna detención a fin de disponer el reparo de que necesitaba la salud de su mujer, harto quebrada de las fatigas de la fuga, destemplanzas de las nieves y sobresaltos del camino» ${ }^{103}$. Ya sin su esposa se trasladó

100. Virginia LeÓn SANZ: Entre Austrias y Borbones, Madrid 1993, p. 184.

101. Alcira estuvo bajo control borbónico entre el 12 de abril y el 9 de junio de 1706, en Eugenio GARCí ALMIÑANA: «La Guerra de Sucesión en la villa de Alzira a través de la correspondencia municipal (1703-1707)》), en Al-Gezira 3 (1987), pp. 193-230.

102. A. H. N. Consejos Leg. 18.476 Memorial del Marqués de la Escala.

103. A. H. N. Consejos Leg. 18.450 Memorial del Conde de Villanueva. 
a Requena, y se puso a las órdenes del conde de las Torres, «e hizo toda la campaña, asistiendo en todas las ocasiones que se ofrecieron, y con especialidad en el ataque de la ciudad de Xátiva, y habiendo V. M. contramandado aquellas tropas, las siguió D. Jerónimo toda la campaña, y aunque V. M. resolvió restituirse a esta Corte, lo continuó agregado de voluntario al regimiento de caballería, de que es coronel el marqués de Pozoblanco, y desde el Campo de Tarazona salió destacado para el ataque a Cuenca, y asistió en todas las ocasiones que se ofrecieron hasta la rendición de esta ciudad» ${ }^{104}$.

De otros titulados valencianos sólo sabemos que se hallaban exiliados en la Corte, y que recibieron $3.800 \mathrm{rls}$. de los bienes embargados a valencianos rebeldes. Así sucede con el marqués del Bosch, que fuera gobernador de Alicante hasta su rendición, con el conde de Almenara, José Antonio Próxita, que dejó Valencia con su mujer y tres de sus hijos, o con Juan Basilio Castellví Coloma, conde de Cervelló, y gobernador de Valencia, que también fue socorrido con igual cantidad en Madrid, pese a que existían dudas sobre su fidelidad, quizá porque no fue muy activo en la defensa de Valencia y porque su familia tuvo a destacados dirigentes austracistas ${ }^{105}$, que finalmente fueron determinantes en su desafección a los Borbones. Fue, no obstante, regidor de Valencia en su primer ayuntamiento ${ }^{106}$, pero también es cierto que su familia fue observada con desconfianza por las autoridades borbónicas, y Rodrigo Caballero afirmó de los Castellvi que «a ninguno de esta familia tengo por seguro», después de que Jaime Castellví Coloma, hermano del conde de Cervelló, rindiera el castillo de Miravete sin ofrecer resistencia y que, cuando la guerra se había ya inclinado de manera decidida hacia Felipe V, apareciera en Morella narrando una rocambolesca huida ${ }^{107}$. En 1710, tras la segunda ocupación de Madrid por el Archiduque, el conde de Cervelló se pasó al austracismo ${ }^{108}$, como lo hizo el Arzobispo Folch de Cardona, también familia suya, exiliándose en Viena en 1713 y alcanzando la Grandeza de España ${ }^{109}$ y un puesto de consejero de la secretaría de la negociación de Sicilia en 1720, cuando aquel reino fue incorporado a la corona austriaca ${ }^{110}$.

Por sus sacrificios y fidelidad, los titulados valencianos solicitaron recompensas variadas para sí o para sus familias. El marqués de Albaida, durante su exilio en la

104. A. H. N. Consejos Leg. 18.476 Memorial del Conde de Villanueva.

105. Kamen dice que «claramente» era austracista, en $O p$. Cit. p. 328.

106. A. H. N. Consejos Lib. 2.494, ff. 46v-47 Real Cédula, Madrid 13 de diciembre de 1707

107. Enrique GIMÉNEZ LÓPEZ: «El peligro austracista en tierras valencianas tras la Guerra de Sucesión», en Anales valentinos 26 (1988), pp.315-329.

108. Amparo FELIPO ORTS: «La repercusión de la política de confiscaciones de Felipe V sobre D. Juan Basilio de Castellví, conde de Cervelló y marqués de Villatorcas», en Estudis 31 (2005), pp. 253-268. Sobre la actividad del conde de Cervelló en su exilio austriaco y sus relaciones con simpatizantes en España, vid. Antonio MESTRE SANCHIS: «Los austracistas: proyectos culturales y crítica política», en Apologia y critica de España en el siglo XVTII, Madrid 2003, pp. 119-165.

109. Pedro Moreno Meyerhoff: «Los Grandes de España creados por el Archiduque en la Corona de Aragón», en Eliseo SERRANo (ed.): Felipe Vy su tiempo, Zaragoza 2004, vol. II, pp. 363-403.

110. Agustí AlCoBerro: L'exili austracista (1713-1747), Barcelona 2002, pp. 127 y 176 y Virginia LEON: Carlos VI. El emperador que no pudo ser rey de España, Madrid 2003, p. 269. 
Corte, demandó se le diera una de las casas confiscadas en Madrid para residir con su familia en sitio decoroso, «y librarse del excesivo gasto que le ocasiona el no tenerla y haber de pagar sus alquileres», y pidió para su hijo, el marqués de Buñol, la merced de gentilhombre de cámara, y para él plaza en el Consejo de Italia o de Indias, «con futura sucesión a ausencias y enfermedades para dicho su hijo» ${ }^{111}$, y recordaba que en el Consejo de Indias existían dos vacantes, dejadas por Juan Larrea y Juan Castro Gallego. El febrero de 1707, ante las escasas posibilidades de que prosperara su súplica, solicitó con otro memorial la plaza de baile general de la ciudad y Reino de Valencia para cuanto este se recuperase ${ }^{112}$. Tuvo que conformarse finalmente con el título de regidor de Valencia, concedido en diciembre de 1707, si bien eximiéndole del pago del derecho de la medianata ${ }^{113}$, una gracia que también obtuvieron muchos de los titulados que salieron de Valencia a primeros de 1706, como los condes de Castellar, Almenara, del Real, Villanueva, Sumacárcer, Parcent y Faura, y los marqueses de la Escala, Mirasol ${ }^{114}$ y Malferit ${ }^{15}$.

También plaza en el Consejo de Indias solicitó el conde de Albalate, José Sorell Roca. Decía en su memorial que había perdido todo lo que tenía en Valencia y Cataluña, y que se hallaba «con la precisión de asistir a su sobrino, que con el mismo motivo dejó su casa, y estaba en paraje de ni poderle vestir ni dar de comer pues le faltaba a sí propio» ${ }^{166}$. El sobrino al que hacía referencia era José Torán Sorell, quien debía heredar el título, ya que José Sorell no tenía descendientes directos, y que logró en 1714 la alcaldía del crimen de la Audiencia de Valencia con la recomendación de Macanaz, quien hizo referencia a la condición de heredero del condado de Albalat de Torán, y a su exilio de 1706: «es caballero que hereda la casa y estado del conde de Albalat; buen letrado, criado en Castilla, siguió al rey en los años de 1706 y 1710. Será una elección muy acertada y aplaudida sobre muy justa» ${ }^{117}$, si bien su primo José Mercader y Torán fue un destacado austracista, ennoblecido en Viena por Carlos VI.

En el período de incertidumbre comprendido entre el triunfo borbónico de Almansa y el decreto de junio de 1707 que abolía los fueros, algunos nombres de los nobles exiliados fueron propuestos, y aceptados por el rey, en el intento postrero del Consejo de

111. A. H. N. Consejos Leg. 18.476 Memorial del Marqués de Albaida. Pasó al Consejo de Aragón el 27 de octubre de 1706.

112. A. H. N. Consejos Leg. 18.476 Memorial del Marqués de Albaida. Pasó al Consejo de Aragón el 28 de febrero de 1707.

113. A. H. N. Consejos Lib. 2.496, ff. 46v-47, Real Cédula, Madrid 13 de diciembre de 1707.

114. Para celebrar la entrada de las tropas de Felipe $V$ en Valencia el marqués de Mirasol concedió carta de libertad a su esclavo negro, en Vicente Graullera: Los notarios de Valencia y la Guerra de Sucesión, Valencia 1987, p. 62.

115. María del Carmen IRLES VICENTE: Al servicio de los Borbones. Los regidores valencianos en el siglo XVIII, Valencia 1996, pp. 20-22.

116. A. H. N. Consejos Leg 18.450 Memorial del Conde de Albalate. Pasó al Consejo de Aragón el 14 de abril de 1707.

117. A. G. S. Gracia y Justicia Leg, 133 Melchor de Macanaz propone sujetos para las plazas vacantes. 
Aragón por mantener la figura del virrey, la continuidad de la Generalidad, si bien eligiendo el rey a sus diputados, y la sustitución del sistema insaculatorio para la provisión de las autoridades municipales por otro sin sorteo, cuyos Justicia y Jurats serían ahora designados directamente por el monarca, aunque la duración de su mandato seguiría siendo anual ${ }^{118}$. El conde de Villanueva, que antes de la recuperación de Valencia decía estar 15 meses y medio fuera de su casa, enfermo y falto de medios al encontrarse desposeído de sus rentas ${ }^{119}$, ya que los austracistas le habían secuestrado la villa de Villanueva, los lugares de la baronía de Castellmontant, Montanejos, Arañuel, Fuente de la Reina, la Baronía de Torres-Torres, y los lugares de Algimia, Alfara, Canet, Godella, Rocafort y El Pujol, fue nombrado el 30 de mayo de 1707 diputado de la nueva Generalitat, junto al arzobispo Folch de Cardona, el conde de Carlet, D. José de Cardona Pertusa, Pedro Luís Blanquer e Ignacio Bojoní120, todos ellos huidos de Valencia tras la entrada de Basset y residentes en Madrid, un nombramiento éste efímero, ya que la Generalitat fue abolida el 29 de junio, cuando quedaron derogados «todos los fueros, leyes, usos y costumbres de los Reinos de Aragón y Valencia, mandando se gobiernen por las leyes de Castilla». Tras ser nombrado regidor de Valencia, en 1713 Villanueva fue compensando con una plaza de consejero de Órdenes, en consideración a su condición de teniente general del Rey en la orden de Montesa, de la que era caballero, desde 1708.

El conde de Carlet, otro de los designados para esa fantasmagórica Generalidad, decía haberse mantenido en Madrid en los primeros meses «con lo poco que pudo sacar de Valencia entre la prisa y el riesgo, pero que consumido ya todo», después de un año, no le quedaba otro recurso que la piedad del rey ${ }^{121}$. Salvo el socorro de 3.800 rls. concedido por el Consejo de Aragón el 14 de abril de 1707, Carlet sólo alcanzó una regiduría en el ayuntamiento valenciano, si bien el presidente de la Chancillería, Pedro Colón de Larreategui, llegó a proponer su nombre para encabezar uno de los nuevos corregimientos que debían sustituir a las gobernaciones forales ${ }^{122}$, en su proyecto frustrado de que contaran con corregidores de capa y espada y de letras en lugar de gobernadores militares.

Cristóbal Crespí de Valldaura, conde de Sumacárcer, suplicó en noviembre de 1706 que Felipe V le honrase «con llave de entrada en la Real Cámara», y que sus encomiendas de Ademuz y Castelfabi, de la orden de Montesa, se prorrogaran una vida más en sus hijos, pues cinco lo habían acompañado al exilio ${ }^{123}$. Sumacárcer recibió

118. A. H. N. Consejos Leg 18.190 Consulta del Consejo de Aragón, 20 de mayo de 1707.

119. A. H. N. Consejos Leg. 18.450 Memorial del Conde de Villanueva.

120. Resolución Real de 30 de mayo de 1707 a la consulta del Consejo de Aragón de 20 de mayo, en Mariano PESET REIG: Bulas, Constituciones y Documentos de la Universidad de Valencia (1707-1724), Valencia 1977, pp. 49-51.

121. A. H. N. Consejos Leg. 18.476 Memorial del Conde de Carlet. Pasó al Consejo de Aragón el 12 de marzo de 1707.

122. Enrique GIMÉNeZ LÓPEZ: Militares en Valencia (1707-1808), Alicante 1990, pp. 21-22.

123. A. H. N. Consejos Leg. 18.476 Memorial del Conde de Sumacárcer. Pasó al Consejo de Aragón el 24 de noviembre de 1706 . 
únicamente el título de regidor de la ciudad de Valencia, título que también recibió el conde del Real, Ximén Pérez de Calatayud, que había visto secuestrados sus señoríos de la villa del Real, y los lugares de Montserrat, Millars, Pedralba, Bugarra, Ráfol de Salem y Beniatjar, y había vivido en Madrid de la caridad del Consejo de Aragón ${ }^{124}$. El marqués de la Escala, solicitó en noviembre de 1706 el empleo de correo mayor de la ciudad y Reino de Valencia para su persona y casa ${ }^{125}$, pero tuvo que conformarse con una regiduría en el primer ayuntamiento borbónico de Valencia ${ }^{126}$. El conde de Parcent, José Cernesio Odescalchi, tuvo un mayor reconocimiento, pues además de la regiduría valenciana, obtuvo en julio de 1709 la merced de grandeza de segunda clase para su casa. Para pagar el derecho de medianata solicitó licencia al rey para vender algunos bienes de sus mayorazgos, como un censo que poseía sobre los lugares de Cuart y Aldaya, y tierras en la huerta de Valencia «hasta en cantidad de ocho mil doblones, o en su defecto cargar esa misma cantidad a censo sobre sus casas y mayorazgos en aquel Reino, con relevación de la prueba de la conversión para que más fácilmente pueda hallar quien compre las heredades u otorgue el censo». Justificaba esas urgencias económicas en «los repetidos contratiempos y excesivos gastos que le han ocasionado las turbaciones del Reino de Valencia», y a la reparación de sus casas en la capital y en el campo, ya que «le saquearon y maltrataron los enemigos» sus propiedades en Parcent, Benigembla, Vernisa, Setla, Mira-rosa, Almàssera y Benferri. La Cámara de Castilla emitió un dictamen contrario a la concesión de esa licencia por «oponerse directamente a la práctica, estilos y leyes de Castilla», que obligaban a un largo y complejo trámite procedimental ${ }^{127}$.

\section{LA NOBLEZA NO TITULADA Y LA FIDELIDAD DE LOS PARTICULARES}

Además del marqués del Bosch, gobernador de Alicante, abandonaron territorio valenciano su procurador patrimonial, Antonio Soler y Seva, el teniente de gobernador de Valencia, Vicente Monsoriu, y el asesor de aquella gobernación, Luis Vicente Salvador Pelegrí, el gobernador de Xátiva, Francisco Rocafull y su teniente, Juan Ortiz de Malferit ${ }^{28}$, el asesor del gobernador de Castellón, Pedro de Benavente, que huyó a Madrid, «constituido en la mayor miseria y necesidad», y suplicando algún destino

124. A. H. N. Consejos Leg. 18.450 Razón de la forma en que parece se podrán distribuir los 141.577 rls., Madrid 13 de diciembre de 1707.

125. A. H. N. Consejos Leg. 18.476 Memorial del Marqués de la Escala. Pasó al Consejo de Aragón el 17 de noviembre de 1706.

126. María Fernanda MANCEBO: «El primer ayuntamiento borbónico de la ciudad de Valencia», en Estudios de Historia de Valencia, Valencia 1977, pp. 293-307.

127. A. H. N. Consejos Lib. 1.911, ff. 46v-49 Consulta de la Cámara de Castilla, Madrid 30 de julio de 1709.

128. Sus bienes fueron confiscados por los austracistas, en Carmen PÉREZ APARICIO: «La política de represalias...», p. 167. 
en la administración territorial castellana ${ }^{129}$. Monsoriu recibió en Madrid la ayuda de 3.800 rls. fijada por el Consejo de Aragón para magistrados y titulados en el exilio, mientras que Rocafull, pese a ser gobernador, sólo recibió 2.000 rls. ${ }^{130}$. El asesor de la gobernación valenciana y Dr. en Derecho Luis Vicente Salvador Pelegrí, que fue comisionado para perseguir bandidos en 1697 por el virrey Alonso Pérez de Guzmán, fue de los primeros en salir de Valencia, pues abandonó la ciudad el último día de 1705. Pasó a Madrid y allí recibió instrucciones de trasladarse de inmediato a Requena, y estuvo en la capital hasta que el empuje de los austracistas le obligó a abandonarla a finales de junio «y venirse a las cercanías de Madrid», dejando en Requena todas sus pertenencias ${ }^{131}$. En Vallecas malvivió en una posada, enfermo, hasta que recibió 2.000 rls. de limosna del Consejo de Aragón.

También se retiró a tierras castellanas el asesor de la bailía general Felipe Ripoll, acompañando al virrey Villagarcía. Ripoll había estado vinculado a la administración de la Hacienda Real en Valencia durante los veinte años anteriores, y en Castilla decía haber estado a punto de perecer «a manos de la necesidad y de la indecencia», pues afirmaba que «habiendo vendido y consumido en quince meses que falta de su casa los pocos efectos que pudo sacar de ella», se encontraba sin poder adquirir los más precisos alimentos ${ }^{132}$, por lo que recibió 2.000 rls. de socorro para sus sustento. El Receptor de les Pucunies de la bailía de Valencia, Juan Milán de Aragón, a diferencia de otros miembros de administración regnícola, obtuvo el socorro máximo de 3.800 rls., probablemente por ser miembro de una familia de distinguida militancia borbónica, y de la que formaban parte nobles titulados, como el marqués de Albaida, dignidades de la catedral, destacados miembros de la orden de predicadores o caballeros de órdenes militares, como Vicente Milán que, junto a Juan, su hermano, había participado en la represión de la revuelta campesina de 1693, Vicente en Jalón con soldados de Moncofa, y Juan en Denia ${ }^{133}$. Por último, también se habían exiliado los integrantes de la bailía de Alicante ${ }^{134}$, su baile general Pablo Martínez de Vera, su teniente Gabriel Palavicino, el tesorero Eusebio Salafranca y el racional y delegado del asesor, Ignacio Palavicino, caballero de Montesa, que se había destacado en la defensa de la ciudad cuando fue atacada por Francisco García de Ávila y por las tropas inglesas. Junto con su hermano Gabriel, que servía interinamente como castellano de la fortaleza de Santa Bárbara, que defendieron hasta el 6 de septiembre de 1706 , en que fue tomada por los regimientos de infantería de Hotham y Sybourg al mando

129. A. H. N. Consejos Leg. 18.476 Memorial de Pedro Antonio Benavent Catalán. Pasó al Consejo el 15 de junio de 1707.

130. A. H. N. Consejos Leg. 18.450 Consulta del Consejo de Aragón, 14 de abril de 1707.

131. A. H. N. Consejos Leg. 18.476 Representación de D. Luis Vicente Salvador Pelegrí.

132. A. H. N. Consejos Leg. 18.476 Memorial de D. Felipe Ripoll. Pasó al Consejo de Aragón el 20 de septiembre de 1706.

133. Sebastián Garcia Martinez: Op. Cit. p. 554.

134. Sobre la Bailia de Alicante, vid. Armando ALBEROLA: Jurisdicción y propiedad de la tierra en Alicante (ss. XVII y XVIII), Alicante 1984, pp. 345-357. 
del Mayor John Richard ${ }^{135}$. Según su testimonio, «cediendo a la fuerza enemiga dejaron ambos el castillo con las capitulaciones que fueron notorias, quedando D. Gabriel, su hermano, y el suplicante errando con sus numerosas familias por los lugares leales de Castilla, habiéndoles los enemigos saqueados todos sus muebles, destruido y confiscado todos sus raíces, y reducidos a la última miseria de la extrema necesidad ${ }^{136}$.

La nobleza no titulada de la ciudad de Valencia, los Caballers, tomaron por lo general una posición proborbónica, y en algunos casos sirvieron al virrey en los frustrados intentos por sofocar la revuelta en su fase inicial. Vicente Milán de Aragón, caballero de la orden de San Juan de Jerusalén, pese a su minusvalía, pues le faltaba un pie que perdió en un combate naval contra una embarcación berberisca frente a Denia, participó con su sobrino el conde de Buñol en la compañía de milicias que pagó su hermano, el marqués de Albaida, y se retiró a Valencia cuando el coronel Nebot, con su regimiento de caballería, se pasó al austracismo ( «maldad execrable», la llamó Miñana), provocando la huida del duque de Gandía a Madrid, la rendición de Alcira el 13 de diciembre sin resistencia, y abriendo la puerta de Valencia a Basset. Ya en la capital, Villargarcía lo empleó en la asistencia de rondas, y salió con el virrey hacia Requena tras la ocupación de la ciudad el 16 de diciembre de 1705. Cuando llegó a la frontera con Valencia Antonio del Valle, se incorporó a sus tropas. Participó en los ataques a Alcira y Xátiva, bajo las órdenes del conde de las Torres, con 18 fusileros pagados a su costa, y cuando el ejército borbónico abandonó territorio valenciano se refugió en Villarejo de Salvanés, hasta que el Archiduque abandonó Madrid, porque la falta de medios le imposibilitó acompañar a Felipe V. En octubre de 1706 solicitó un subsidio, o un empleo «en mar o tierra» ${ }^{137}$, y el Consejo de Aragón le entregó 2.000 rls., mientras que su hermano Cristóbal, que también lo acompañó al exilio, recibió únicamente 600 .

Los hermanos Dionisio y Tomás Ros Castelví también recibieron un trato similar. Dionisio obtuvo 2.000 rls. de bienes confiscados, mientras que Tomás tan sólo 500 rls. Los servicios del primero eran muy superiores a los de Tomás, mero acompañante de su hermano. Dionisio Ros era caballero de Montesa, barón de Almiserà, en la comarca de La Safor, y auditor de las tropas del rey en Valencia. Cuando tuvo lugar el desembarco aliado en Denia se dirigió a combatirlo, y fue hecho prisionero en Gandía, de donde pudo escapar y refugiarse en Castilla con su mujer y sus ocho hijos. En Madrid encontró cobijo en una casa propiedad del duque de Gandía, cerca de Caballero de Gracia ${ }^{138}$, donde residía en compañía de Andrés Berdún, un servidor de la casa ducal, cuyos hijos también la sirvieron, Ignacio Berdún como secretario del conde de Benavente,

135. David Francis: The First Peninsular War, 1702-1713. Londres, 1975, pp. 272-275.

136. A. H. N. Consejos Leg. 18.476 Memorial de D. Ignacio Palavicino. Pasó al Consejo de Aragón el 9 de mayo de 1707.

137. A. H. N. Consejos Leg. 18.476 Memorial de D. Vicente Milán de Aragón. Pasó al Consejo de Aragón el 12 de octubre de 1706.

138. A. H. N. Consejos Leg. 18.476 Testimonio a favor de D. Gaspar de Castelvi, Madrid 6 de noviembre de 1706 . 
y autor de la obra Derechos de los condes de Benavente a la Grandeza de Primera Clase, que se publicaría en Madrid en 1753, y Francisco como abogado, llegando a ser posteriormente alcalde mayor de Valencia y Murcia, y corregidor de distintas poblaciones valencianas. Dos de los ocho hijos de Dionisio Ros, Francisco y Jerónimo Ros Malferit, caballeros de Montesa, sirvieron junto a su padre en las proximidades de Denia y, posteriormente a las órdenes del coronel Pedro Corbí. Durante su exilio en Madrid reivindicaron sus servicios, y solicitaron plaza de capitán en regimientos de caballería e infantería. Dionisio Ros fue premiado con una alcaldía del crimen de la Chancillería de Valencia en 1713, pero falleció antes de poder tomar posesión ${ }^{139}$.

Pedro Luis Blanquer poseía experiencia militar en las campañas del frente catalán contra Francia, pues había vivido la derrota del Ter en 1694, sufrido la demolición de Castellfollit un año después por el duque de Vendôme, y los sitios de Hostalric en 1696 y Barcelona en $1697^{140}$, y en la frontera extremeña. Por esa razón fue enviado por el virrey Villagarcía a Denia «a poner en armas a la gente de aquellos contornos, como lo ejecutó, y por encargo del mariscal de campo D. Luis de Zúñiga desalojó a los rebeldes de los puertos de Sorel y Sagra, de cuya ejecución volvieron a la debida obediencia de V. M. todos los lugares hasta las murallas de Denia, donde asistió a la quema de su arrabal, retirándose después, y con nuevo orden pasó a la villa de Vinaroz, lugar de frontera, porque se había entregado Tortosa a los rebeldes, la que encontró poseída y guarnecida de enemigos, lo que avisó a dicho virrey, y se le mandó pasase al castillo de Morella, aplicándose dos meses a su defensa». Cuando intentó regresar a la ciudad de Valencia para participar en su defensa, ya era tarde, tuvo que huir a Aragón, y pasó a Madrid para participar con Felipe $V$ en el ejército que sitió Barcelona en la primavera de $1706^{141}$, y tuvo que retirarse a Francia, acompañando al rey en su regreso a España, y en Atienza, donde se había acantonado el ejército borbónico para recuperar la iniciativa y volver a tomar Madrid, «enfermó de las fatigas padecidas en el camino, y de alli siguió a V. M. a esta Corte» ${ }^{142}$. Quien sufrió por las actividades borbónicas de Blanquer fue su familia, que permaneció en Valencia. Acusado de traidor e incendiario, sus hermanos fueron puestos en prisión y saqueadas sus propiedades.

Los caballeros Jorge Núñez Valterra, Jaime Borrás, Gaspar Castelví Grau Arellano, Tomás March Vives y Pedro Ruiz Lihori al igual que Dionisio Ros, eran señores de vasallos. Núñez Valterra era titular de los señoríos de Samper, Selva y Cartaina. Acompañó a las tropas del conde de las Torres, y con ellas intervino en el ataque a Alcira «manteniendo a sus costas porción de gente». Estuvo de guarnición en el castillo del Montesa, y de allí pasó a Villarejo de Salvanés, junto al marqués de Albaida y Vicente Milán de Aragón. Núñez Valterra pretendió el título de marqués, y que su señorío de Samper

139. Pete Molas Ribalta: La Audiencia...p. 22.

140. Antonio Espino Lopez: Catalumya durante el reinado de Carlos II, Barcelona 1999, pp. 152-202.

141. Joseph Maria Torras I RiBe: La Guerra de Successió i els setges de Barcelona, Barcelona 1999, pp. 170-175.

142. A. H. N. Consejos Leg. 18.450 Memorial de D. Pedro Luis Blanquer: 
quedara desagregado de Xátiva ${ }^{143}$, deseando para él la plena jurisdicción. Obtuvo, sin embargo, el título de regidor de Valencia en el primer ayuntamiento borbónico, como también lo lograron los caballeros exiliados Jaime Borrás, barón de Palanques y Hortells, Antonio Escrivá ${ }^{144}$, Francisco Milán de Aragón, José Cardona Pertusa, Félix Falcó y Jerónimo Valterra, hijo del barón de Petrés, que el 4 de abril de 1707 fue nombrado Lugarteniente de la Orden de Montesa ${ }^{145}$. Gaspar Castelví era titular de los señoríos de Benafer y Erragudo, en el Alto Palancia. Intervino activamente en la defensa de la ciudad de Valencia en 1705 como capitán de una compañía de milicias, «donde amenazaban los mayores riesgos de la sublevación, y especialmente en la puerta de San Vicente, donde consistía el mayor y más crecido número de los sublevados que solicitaban la rendición». Se refugió en el edificio del Santo Oficio con su mujer, Teresa Sanz de Castelví, mientras su casa era saqueada, con temor a que se asaltara su escondite. Pudo escapar «milagrosamente» disfrazado de inquisidor en uno de los coches del tribunal, y pasó a Madrid. No sólo le fueron secuestrados sus señoríos de Benafer y Erragudo, sino las cinco alquerías que poseía en la Huerta de Campanar, en las afueras de Valencia, «que es lo más precioso y estimable de aquel Reino», y heredades en diferentes localidades valencianas, como Foyos, Albal, Burjasot y Torrente, «de forma que después de lo perdido y saqueado la renta que importan estos bienes llegará a cuatro mil pesos anuales con que me mantenía con el lucimiento correspondiente a mi calidad, con coches tiro de cuatro mulas, dos caballos y crecida familia» ${ }^{146}$. Aunque durante su exilio en la Corte Gaspar Castelví pretendió una plaza de capa y espada en el Consejo de Hacienda ${ }^{147}$, sólo fue recompensado con una regiduría en su ciudad natal. Tomás March Vives era barón de Pobla Llarga, en la Ribera Alta. Cuando en agosto de 1705 tuvo noticia de la pérdida de Denia se puso al frente de doce de sus vasallos, a los que dio armas y caballo, y se puso a las órdenes de Francisco Rocafull, gobernador de Xátiva y, posteriormente, a las del teniente general Salazar y del Mariscal de Campo Zúñiga, participando en el incendio del arrabal de Denia. Cuando se perdió la capital, March se unió a las tropas del conde de las Torres, y fue guía de Mahony «como inteligente y experimentado en aquel País», y pudo formar una compañía de infantería, con patente de capitán para Miguel Jacinto Gisbert. Tuvo que refugiarse en Madrid, con su mujer y familia, y decía en su memorial de solicitud de socorro que había «vendido hasta los caballos», por lo que suplicaba el

143. A. H. N. Consejos Leg. 18.476 Memorial de D. Jorge Núñez Valterra. Pasó al Consejo de Aragón el 29 de noviembre de 1706.

144. La condición de Caballero de Antonio Escrivá Híjar era dudosa. Poseía los señoríos de Torre de'en Lloris y Miralbó, recibió 1.000 rls. de socorro durante su exilio en Madrid, y fue nombrado regidor en el primer ayuntamiento borbónico, pero el presidente de la Chancillería, Pedro Colón, manifestó sus escrúpulos a que entrara en la corporación con espada, en María del Carmen IRLES VICENTE: El régimen municipal...pp. 53-57.

145. Fernando ANDRÉs RoBRes: Op. Cit. p. 43.

146. A. H. N. Consejos Leg. 18.476 Memorial de D. Gaspar Castelvi Grau Arellano.

147. A. H. N. Consejos Leg. 18.476 Memorial de D. Gaspar Castelvi Gran Arellano. Madrid 13 de diciembre de 1707 
título de marqués, que se le denegóitis. Por último, Pedro Ruiz Loheri, barón de Alcalalí, Mosquera y la Llosa y señor de Alfarrasí, era hermano de José Ruiz Loheri, que también vio sus bienes confiscados y fue desterrado de Valencia el 10 de abril de $1706^{149}$. Pedro Ruiz estaba al frente de la milicia formada por los gremios de la capital en 1705, dado que contaba con prologados servicios en la vigilancia de la costa y había servido como voluntario en Cataluña en las guerras franco-españolas del reinado de Carlos II. Cuando cayó Valencia fue encarcelado durante más de dos meses, y ya en libertad escapó de la ciudad, dejando atrás un patrimonio que le rentaba anualmente unos 7.000 pesos, y a su mujer y sus cuatro hijos que tuvieron que refugiarse en un convento. De sus señoríos, tres fueron quemados y su casa de Valencia saqueada, «sin dejarle cosa, pues se llevaron hasta las mantillas de sus hijos $\rangle^{150}$. Se agregó al regimiento de Órdenes Viejo de Castilla, interviniendo en choques armados en Alcira, Cullera y Xátiva, hasta que tuvo que pasar a la Corte, donde se quejó amargamente por recibir únicamente $1.000 \mathrm{rls}$. de socorro, lo que consideró ofensivo para quien esperaba ser nombrado coronel. Ciertamente Ruiz Loheri, que vivía en una posada en la madrileña calle Silva y acumulaba una deuda de tres meses por su manutención, tenía la salud deteriorada, y consideraba «agravada su estimación» por haber sido incluido en el tercer grupo de los que recibían ayuda del Consejo ${ }^{151}$, y haber sido denegada su solicitud de obtener el grado de coronel por haberlo sido de milicias urbanas y no tener patente real.

Otro de los solicitantes de título de marqués fue el valenciano Juan Ruíz de Corella, que había sido gobernador del condado de Cocentaina por designación de su titular el conde de Santiesteban. Tres meses antes del ataque a Denia tenía bajo su responsabilidad la defensa de Morella, de donde salió para acompañar al regimiento de Dragones de Miguel Pons y Mendoza, hermano del conde de Robres, para recuperar Alcañiz ${ }^{152}$ y defender Fraga y Monzón ${ }^{153}$, y posteriormente al marqués de Pozoblanco en sus incursiones por tierras valencianas, hasta que finalmente se recluyó en la Corte ${ }^{154}$. Le acompañó al exilio el morellano Pablo de Pedro Sebastián, que también sirvió bajo las órdenes de Miguel Pons en tierras de Aragón ${ }^{155}$.

148. A. H. N. Consejos Leg. 18.476 Memorial de D. Tomás March Vives. Pasó al Consejo de Aragón el 7 de marzo de 1707.

149. Carmen PÉREz APARIClO: «La política de represalias...», p. 171.

150. A. H. N. Consejos Leg. 18.450 Memorial de D. Pedro Ruiz Lohery. Pasó al Consejo el 11 de junio de 1707.

151. A. H. N. Consejos Leg. 18.450 Razón de la forma en que parece se podrán distribuir los 141.577 rls. confiscados.

152. Nicolás Belando: Op. Cit. I, p. 210.

153. Conde de Robres: Historia de las Guerras Civiles de España, Zaragoza 1882, pp. 254-255.

154. A. H. N. Consejos Leg. 18.476 Memorial de D. Juan Ruiz de Corella Vergada. Pasó al Consejo de Aragón el 1 de marzo de 1707, y su solicitud de título de Marqués fue denegada en consulta de 10 del mismo mes.

155. A. H. N. Consejos Leg. 18.476 Memorial de Pablo de Pedro Sebastián. Pasó al Consejo el 26 de marzo de 1706 . 
Otros integrantes de la pequeña nobleza de la ciudad de Valencia también colaboraron con el virrey en el verano y otoño de 1705. José Cardona estuvo con José de Salazar, y cuando sus tropas dejaron Valencia participó en las labores de vigilancia nocturna de la ciudad hasta que huyó a Utiel con su mujer y familia y, posteriormente, tras «divagar por varios lugares de Castilla», llegó a Madrid. Sus cuatro heredades, «de las mejores de la Huerta de Valencia», fueron saqueadas, y calculó las pérdidas en más de 6.000 doblones ${ }^{156}$. Otro de los nobles valencianos, Carlos Vidal Alcocer Monpalau, cayó prisionero de los austracistas y fue encarcelado en Xátiva, pero después de 40 días de presidio logró escapar y se enroló en el regimiento del marqués de Pozoblanco, con caballo y armas a su costa, «habiendo sido preciso vender hasta los vestidos y caballos, despidiendo dos criados para poder alimentarse ${ }^{157}$. Ya en el exilio madrileño, donde también se encontraban tres de sus hermanos, solicitó el grado de capitán de caballos, pero únicamente recibió un socorro de $600 \mathrm{rls}$. que, en su opinión, le desmerecía ${ }^{158}$. El también noble Vitorino García Villanueva, nieto y sobrino de magistrados de la Audiencia foral ${ }^{159}$, se agregó al regimiento de Antonio Montenegro tras salir de Valencia hasta que la enfermedad le obligó a marchar a Madrid ${ }^{160}$, y por situaciones similares pasaron José Jofre ${ }^{|6|}$ y Diego Mercader Carcajona, hijo del barón de Cheste, que acompañó al conde de las Torres primero, sirvió en el regimiento de Pedro Ronquillo después, y posteriormente estuvo a las órdenes de Daniel Mahony en la defensa de Alicante ${ }^{162}$.

156. A. H. N. Consejos Leg. 18.476 Memorial de D. José Cardona Pertusa. Pasó al Consejo de Aragón el 9 de marzo de 1707. Obtuvo título de regidor de la ciudad de Valencia el 13 de diciembre de 1707, en A. H. N. Consejos Libro 2.494, ff. $46 \mathrm{v}-47$.

157. A. H. N. Consejos Leg. 18.476 Memorial de D. Carlos Vidal. Pasó al Consejo de Aragón el 21 de febrero de 1707 .

158. A. H. N. Consejos Leg. 18.450 Memorial de D. Carlos Vidal. Pasó al Consejo de Aragón el 24 de mayo de 1707 .

159. Era nieto, por parte de padre, de Francisco Luis Ariño, que fue Oidor civil entre 1610 y su fallecimiento en 1626, y de Jaime García por parte de madre, Oidor criminal entre 1646 y su muerte en 1649. Era, a su vez, sobrino del Oidor de causas civiles Francisco Aguirre.

I60. A. H. N. Consejos Leg. 18.476 Memorial de D. Vitorino Garcia Villamueva. Pasó al Consejo el 9 de octubre de 1706. Suplicaba una de las cuatro coadjutorías del oficio de Mestre Racional del Reino de Valencia, que había quedado vacante por muerte de Luis Terrera.

161. Jofre abandonó su casa y hacienda y se agregó a las tropas borbónicas «hasta que faltándole los medios, la necesidad le obligó a venirse a esta Corte, donde se halla sin tener de qué alimentarse y con tanta desnudez que no tiene más camisa que la lleva encima»., en A H N Leg, 18476 Memorial de D. José Jofre. Pasó al Consejo de Aragón el 14 de febrero de 1707.

162. Daniel Mahony, de origen irlandés, levantó a su costa un Regimiento de Dragones irlandeses, por lo que recibió el grado de Coronel. Ascendido en mayo de 1705 a Brigadier, se encontraba en 1706 defendiendo Alicante como Gobernador y ya con el grado de Mariscal de Campo, que había recibido en febrero de ese año. Su defensa de la plaza le valió el título de Conde de Mahony en noviembre de 1706, y un mes después fue destinado al gobierno de Cartagena. Murió el 10 de enero de 1714 como Teniente General. 
De los ocho regidores de la ciudad de Valencia de la clase de ciudadanos, al menos seis vivieron el exilio. Juan Bautista Bordes procedia de Denia, donde era administrador de la Rentas Reales desde 1696, y por ese motivo «le saquearon su casa y talaron sus campos», y tuvo que huir a Castilla tras dejar escondidas en un convento de Valencia a una hija y dos hermanas, donde pretendió una de las cuatro coadjutorías de mestre racional en octubre de $1706^{163}$. Coadjutor del mestre racional por dote de su mujer Vicenta Palop, era Claudio Bonavida, cuyas propiedades fueron confiscadas por el gobierno austracista en diciembre de $1705^{164}$. Tras la recuperación de Valencia recuperó su cargo, ahora con el nombre de contador de la contaduría de la ciudad, y cuando fue nombrado regidor hubo dudas sobre la incompatibilidad de los dos cargos, pero fue confirmado en febrero de 1708 , declarándose compatibles ambos oficios ${ }^{165}$. El tercero de los regidores de la clase de ciudadanos era Miguel Jerónimo Llop, un abogado que ejercía para la ciudad, para la Inquisición y para la Santa Cruzada en 1705 , y que fue nombrado Racional tras la toma de Valencia en de mayo de $1707^{160}$. Cuando fue atacada Valencia se presentó ante el virrey con armas y caballo al considerarse ciudadano de inmemorial y, según su testimonio, «salió fugitivo a pie y con mucho peligro, abandonando cuanto tenía ${ }^{167}$. Fue auditor de las tropas del conde de las Torres, y posteriormente se agregó en Uclés al regimiento del marqués de Pozoblanco hasta que se refugió en Madrid. También estuvo en Madrid, «con alguna indecencia en el vestido», el que sería regidor Isidro Costa de Alón ${ }^{168}$, acompañado de los desterrados Félix Cebriá, Juan Bautista Ramón y José Rivera Borja, como aquel receptores de la cédula de regidores ciudadanos de Valencia fechada el 30 de diciembre de 1707.

La pequeña nobleza alicantina fue mayoritariamente felipista. En diciembre de 1708, con el casco urbano de Alicante ya recuperado para las armas borbónicas, aunque no el castillo que coronaba el monte Benacantil, Macanaz escribió a Grimaldo desde la ciudad para señalar que «todas las familias primeras que no estaban en el reino de Murcia, o en otros lugares, se embarcaron, quedando solas las miserables ${ }^{169}$. De hecho, el oidor de la nueva Chancillería valenciana, el castellano Tomás Melgarejo y Gamboa, nombrado juez de confiscados de Alicante, elaboró un listado de 274 nom-

163. A. H. N. Consejos Leg. 18.476 Memorial de D. Juan Bautista Bordes. Pasó al Consejo de Aragón el 17 de octubre de 1706.

164. Carmen PÉREZ APARICIO: «La politica de represalias...», p. 155.

165. A. H. N. Consejos Lib. 2.494, ff. 83v-85.

166. Sergio VILLAMARTIN GÓMEZ: «La organización del primer ayuntamiento borbónico en Valencia (17071709)», en Eliseo Serrano (ed.): Felipe Vy su tiempo, Zaragoza 2004, vol. II, pp. 491 -509.

167. A. H. N. Consejos Leg. 18.450 Memorial de D. Miguel Jerónimo Llop. El 14 de abril de 1707 recibió I.600 ris. de socorro por vía del Consejo de Aragón.

168. A. H. N. Consejos Leg. 18.450 Memorial de D. Isidro Costa de Alón. El 15 de junio de 1707 recibió 15 doblones de limosna.

169. A. H. N. Estado Leg. 350 Melchor de Macanaz a José Grimaldo, Alicante 9 de diciembre de 1708. 
bres que habían podido justificar su fidelidad borbónica, de los que 37 eran caballeros y ciudadanos ${ }^{170}$.

Cuando era previsible la distribución del territorio valenciano en corregimientos y se meditaba sobre el perfil de sus titulares, la Cámara de Castilla solicitó a la Chancillería de Valencia información sobre valencianos que unieran a su condición de fieles borbónicos la de ser personas prestigiadas y capaces, para tenerlos en cuenta a la hora de proponer nombres para los futuros corregimientos. La lista elaborada por el tribunal ${ }^{171}$ incluía a miembros de destacadas familias valencianas que habían sufrido persecución y exilio durante la contienda sucesoria. Y entre ellos se encontraban los alicantinos Nicolás Pérez de Sarrió, Pedro Burgunyo y José Fernández de Mesa. E1 primero era señor de Formentera, en la Vega Baja del Segura, y había participado en la defensa de la ciudad contra los austracistas, exiliándose a Castilla; el segundo era hermano del magistrado de la Chancillería y antiguo miembro de la Audiencia foral Juan Alfonso Burgunyo, y también se había distinguido en la defensa del castillo de Alicante como sargento mayor de la plaza, primero contra los ataques de Francisco García de Ávila, en los momentos iniciales de la guerra, y posteriormente hasta la rendición del conde de Mahony ${ }^{172}$, con el que se embarcó para Cádiz, tras aceptar las capitulaciones de rendición, y de allí se trasladó a Madrid, donde solicitó ingresar en algún regimiento y que se concediera la castellanía de Alicante, con grado de coronel ${ }^{173}$. En febrero de 1709 , ya recuperada Alicante, sería nombrado regidor decano de la primera corporación alicantina ${ }^{174}$. El tercero de los propuestos, José Fernández de Mesa, pertenecía a una de las más señaladas familias alicantinas. Durante la guerra había sido teniente del gobernador de la ciudad, el marqués del Bosch, y se vanagloriaba de haber actuado con rigor y haber encarcelado a muchos sospechosos para mantener la seguridad de la plaza, «sin que la piedad y dependencia de paisanos limitase el rigor que correspondía a tomar las resoluciones más convenientes». Pasó a Murcia para solicitar al obispo Belluga el envío de tropas de socorro y víveres a Alicante, cuando la ciudad estaba sitiada. No pudo reincorporarse a la defensa del castillo y quedó preso en las cárceles de la ciudad junto con su padre, Gaspar Fernández de Mesa, ya octogenario. De allí «fueron sacados por las calles públicas, y atados los pasaron con otros buenos vasallos de diversas clases a las cárceles de Elche». Murió su padre, y pudo escapar de Elche y refugiarse en Murcia. Fue premiado con una regiduría de la clase de nobles, y en 1715 solicitó llave de gentilhombre de cámara del Rey, pretensión que, pese a contar con el

170. Jesús Pradells Nadal: Del foralismo al centralismo. Alicante 1700-1725, Alicante 1984, pp. 167178.

171. Joan Mercader dio a conocer esa relación de candidatos valencianos. Cfr. Joan MERCADER RIBA: Felip $V$ i Catalunya, Barcelona 1968, pp. 257-259.

172. Jesús Pradells Nadal: Op. Cit. pp. 70-73.

173. A. H. N. Consejos Leg. 18.476 Memorial de D. Pedro Burgunyo Remiro.

174. A. H. N. Consejos Lib. 2.494 f. $281 \mathrm{v}$. 
beneplácito de la Cámara, y una resolución real que apuntaba escuetamente «lo tendré presente» ${ }^{175}$, no llegó a concretarse.

Los hermanos Ignacio y Gabriel Paravecino, también miembros de la nobleza alicantina, y caballeros de Montesa, se destacaron en la defensa del castillo, del que el segundo era castellano en funciones. Abandonaron Alicante cuando se formalizó la capitulación de la fortaleza, y ambos quedaron «errando con sus numerosas familias por los lugares leales de Castilla, habiéndoles los enemigos saqueado todos sus muebles, destruido y confiscado todos sus raíces, y reducidos a la última miseria de la extrema necesidad ${ }^{176}$. Ignacio Bojoni, por su condición de Jurat en 1706 , fue detenido y llevado preso a bordo de uno de los navíos ingleses que habían apoyado la toma del castillo. Cuando fue devuelto desnudo a la ciudad escapó a Castilla con su mujer y sus cinco hijos, y llegado a Madrid solicitó un título nobiliario «para sí y todos sus descendientes» ${ }^{177}$, que fue desatendido con una escueta anotación del Consejo de Aragón de 7 de junio de 1707: «nada» ${ }^{178}$. Otro de los Jurats, Juan Bautista Sirera, pasó por idéntica humillación, que describió con detalle: «y para saciar su venganza los enemigos le condujeron a bordo de un navío en donde le tuvieron en carnes vivas, cargado de prisiones, amenazándole con que le habían de ahorcar a él y' a otros camaradas suyos, poniendo los cordeles a la vista para acongojarles más, apellidándoles de traidores a su rey legítimo, y que como rebeldes e inobedientes les habían de hacer morir. $Y$ entre tanto llegase la hora de la operación les quitaron por tres días naturales el sustento de comida y bebida, y pasando los dieron unas habas tan asquerosas y podridas que no era posible comerlas; y para cubrir sus carnes les dieron a cada uno una camisa de terliz embreada, la que les ocasionaba mayor tormento. Y después de este tiempo los bajaron a la bodega del navío para privarles de la luz y la vista de la gente, teniéndoles en prisiones, y con la imposibilidad de moverse a un lado y a otro. Y después de este riguroso tratamiento los volvieron a tierra, llevándoles a casa del brigadier inglés, quien después de pasado un día les dio libertad sin que el suplicante, ni ninguno de los jurados que estaban juntos pudiesen tener ningún alivio por haberles saqueado generalmente cuanto tenían en sus casas, y el suplicante asegura a V. M. que lo que perdió pasa de más de cuatro mil doblones, de que resulta el total desamparo y recurso para alimentarse a sí, a su mujer e hijos. Salió de la ciudad casi en carne vivas y a píe por venir a los lugares de V. M. que no habían padecido la desgracia de dicha ciudad, en cuyo tránsito padeció lo que no es ponderable, por faltarle los medios y las fuerzas que por el maltrato que le hicieron los enemigos le redujeron casi al último trance de su vida $\rangle^{179}$. Una descripción que resulta válida por otros testimonios que contaron esa misma vejación, como el de Francisco Vergara Mallebrera, que también sufrió «violentas barbaridades» a bordo de un

175. A. H. N. Consejos Lib. 1913, ff. 77-79 Consulta de la Cámara de Castilla, Madrid 22 de enero de 1716.

176. A. H. N. Consejos Lib. 18.476 Memorial de D. Ignacio Paravecino.

177. A. H. N. Consejos Lib. 18.476 Memorial de D. Ignacio Bojoni Scorcia.

178. A. H. N. Consejos Lib. 18.450 Minuta del Consejo de Aragón, 7 de junio de 1707.

179. A. H. N. Consejos Lib. 18.476 Memorial de D. Juan Bautista Sirera. 
buque inglés, antes de escapar con su mujer y siete de sus hijos $\rangle^{180}$. Al igual que Bojoní, también solicitó título nobiliario Francisco Pascual de Ibarra, que se había destacado en la solución del problema de las bandositats de la Marina desde 1679, siendo asesor del baile general de Alicante, por comisión del duque de Veragua, cuando «estaban el campo y los caminos sin cultivo, ni libertad, habiendo embarcado 120 parciales a los presidios de Italia ${ }^{18 !}$, en realidad fruto de la negociación con algunos de los cabecillas, con la oferta de que se trasladasen a Milán como soldados durante tres años, formando compañía bajo la capitanía de su jefe del grupo, en este caso Eugenio Cruanyes ${ }^{182}$. Muerto en el exilio madrileño sin haber logrado el título de marqués que solicitaba, su viuda, Josefa Alfonsa Martínez de Vera, hermana del marqués del Bosch, solicitó socorro para los siete hijos, dos varones y cinco doncellas, que dependían de ella, y que a Ventura, su hijo mayor, se le hiciera merced de una compañía de caballos ${ }^{183}$.

Entre los que salieron de Alicante acompañando a Daniel Mahony a Cádiz y posteriormente a Murcia, se encontraban alicantinos que solicitaron gracias y mercedes diversas. Bartolomé Martín, que participó en la recuperación de Cartagena, y con su familia asilada en Murcia, pretendió la capitanía del puerto de Alicante con la superintendencia de su comercio y derecho a asistir a las juntas de salud. El Consejo de Aragón consideró que sin haber controlado por entero el territorio valenciano toda concesión de oficios era prematura por los «inconvenientes en conceder semejantes gracias hasta la recuperación de Valencia, en cuyo caso podrá V. M., con más entero conocimiento, pasar a premiar a los que se hubieren señalado en su real servicio, y así por esto, como por no tener noticia de lo que pretende este sujeto, como por haber sido V. M. servido por su Real Decreto de 22 del pasado hacerle merced, y a otros dos hermanos suyos de 400 ducados de plata de renta a cada uno en bienes confiscados, entiende que V. M. puede servirse mandar se excuse la gracia que suplicas ${ }^{184}$, y el soldado de milicias locales Felipe Martínez, «que había logrado quitar un estandarte de la Reina Ana» cuando intervino en la toma de Elche, pidió un «empleo correspondiente a dicho servicio» ${ }^{185}$.

Entre los letrados con experiencia en la administración foral, y que al igual que los anteriores habían sufrido atropellos y pérdidas de familiares y patrimonio, también se encontraban nombres alicantinos, como los de José Milot, que fue asesor del gobernador de Alicante, Domingo Corsiniani, auditor de la capitanía de la ciudad, o Benito Arques Mingot, que desde 1698 ejercía el cargo de provisor de municiones y armas de Alicante, y que pudo escapar en 1706, tras soportar diversas vejaciones y ver sus propiedades rústicas taladas, a Elda y Jumilla, hasta recalar en Murcia, dejando en el camino a su padre, su mujer y dos de sus hijos, muertos por «la mucha necesidad y

\footnotetext{
180. A. H. N. Consejos Lib. 18.476 Memorial de D.Francisco Vergara Mallebrera,

181. A. H. N. Consejos Lib. 18.476 Memorial de D. Francisco Pascual de Ibarra.

182. Sebastián García Martínez: Op. Cit. pp. 213-214.

183. A. H. N. Consejos Lib. 18.476 Memorial de $D^{a}$ Josefa Alfonsa Martinez de Vera. Pasó al Consejo de Aragón en 25 de marzo de 1707.
}

184. A. H. N. Leg. 18.476 Consulta del Consejo de Aragón, Madrid 10 de marzo de 1707.

185. A. H. N. Leg. 18.476 Memorial de Felipe Marin. 
miseria $\rangle^{196}$. Todos ellos fueron premiados con regidurías de Alicante en la clase de ciudadanos ${ }^{187}$, y con ellos también es posible encontrar numerosos particulares que adujeron servicios relevantes para obtener algún tipo de ayuda, como la viuda de D. Nicolás Escorcia, Josefa Escorcia Nogueroles, refugiada en Murcia, pese a que los austracistas «le ofrecieron varios partidos de gran conveniencia», o Bautista Orts, Justicia del lugar de San Juan, en la huerta de Alicante, que informó a las autoridades de la ciudad de los movimientos de Francisco García de Ávila en el primer asedio que sufrió Alicante, y que por ello tuvo que huir a Castilla con su familia ${ }^{188}$.

En la vecina Hoya de Castalla se concentró uno de los núcleos más numerosos de partidarios de Felipe V en Valencia. De esa comarca llegaron las milicias que apoyaron a los borbónicos alicantinos que defendían la ciudad de los campesinos armados de Francisco García de Ávila ${ }^{189}$, y de la villa de Ibi, una de sus poblaciones, partió uno de los más reputados borbónicos valencianos, Pedro Corbí, con 100 hombres de Onil, Castalla, Xixona y Bañeres para ponerse a las órdenes del mariscal Luis de Zúñiga en su intento de sofocar la revuelta en la Marina y recuperar Denia. Hecho prisionero tras el paso de Rafael Nebot al austracismo, y conducido por Basset a Valencia, pudo escapar y regresar a su comarca, donde levantó a más de 1.000 hombres que aseguraron la fidelidad de la Hoya, y acompañaron a Belluga en el sitio de Onteniente y en su cuartel general de Villena, en la frontera castellana con Valencia ${ }^{190}$, colaborando con el obispo en evitar que Fuente la Higuera cayera en manos austracistas. En marzo de 1706, Corbí suplicó el empleo de capitán de caballos, con su sueldo correspondiente, para que su mando fuera más eficaz, o como él mismo señalaba en su memorial ««para con más graduación poder acalorar estas milicias, y que éstas le obedezcan para tenerlas prontas para el resguardo de Alicante y rincón de este Reino, por ser las villas de Ibi, Tibi, Xixona, Castilla, Onil, Biar, Elda, Petrel y Monóvar el antemural de él y de Castilla, y dichas villas claman porque el suplicante sea su capitán, habiéndole seguido sus vecinos con voluntad y valor en todas las referidas funciones $\rangle^{191}$. Se unió a la tropas vencedoras en Almansa, y obtuvo el grado de coronel. En 1709 fue nombrado gobernador militar y corregidor de Xixona, villa que había recibido el 20 de junio de 1708 el título de ciudad y capital de la comarca de la Hoya por «las circunstancias tan apreciables de honor, lustre y nobleza que la asisten, y a lo que ha gastado en la manutención y alojamientos repetidos de mis reales tropas, y a lo mucho que ella y sus hijos solicitaron la defensa de la plaza y castillo de Alicante, y exponiéndose varias veces por introducir en ella los socorros necesarios, al

186. Jesús Pradells Nadal: Op. Cit. p. 166.

187. A. H. N. Consejos Lib. 2. 494, ff. $282 \mathrm{v}$.

188. A. H. N. Consejos Leg. 18.450 Memorial de Bautista Orts. Recibió una ayuda de 15 doblones, en íbidem. Memoria de los sujetos a quienes V. M. pude servirse mandar socorrer. Madrid, 15 de junio de 1707 .

189. Nicolás BeLANDo: Op. Cit. vol. I, p. 247.

190. Juan Bautista VILAR: El Cardenal Luis Belluga, Granada 2001, pp. 53-58.

191. A. H. N. Consejos Leg. 18.746 Memorial de D. Pedro Corbi. Pasó al Consejo de Aragón el 5 de marzo de 1706 . 
evidente riesgo de la vida, además de servirme a expensas propias dentro de su castillo, donde murieron algunos durante el penoso y porfiado sitio que padeció; y atendiendo también a la especialísima fidelidad con que en todos tiempos se ha mantenido dicha villa, y que tan constantemente lo ha acreditado en las turbaciones de dicho Reino de Valencia, siendo una de las primeras ciudades y villas de él que tomó las armas en su defensa por singularizarse en el afecto y amor a mi Real persona $\rangle^{192}$. Corbí fue corregidor de Xixona hasta su fallecimiento en mayo de 1753, aunque con el grado de brigadier que había obtenido en 1747 por su actuación contra los corsarios berberiscos en la Marina de Elche, perteneciente al territorio de su corregimiento ${ }^{193}$. Alguno de sus colaboradores más cercanos durante la guerra, como Francisco García Ibáñez, vecino de Xixona, recibió la patente de capitán de granaderos, y suplicó en febrero de 1707 el privilegio de nobleza ${ }^{194}$, y el gobernador del castillo de Bañeres, Raimundo Casamayor, tenía como motivo de orgullo que su fortaleza, junto a las de Peñíscola y Montesa, eran las únicas valencianas que se habían mantenido fieles a Felipe V, pese a haber «sido sitiado en dieciséis ocasiones por los enemigoss ${ }^{195}$. Todas las poblaciones que comprendían el territorio controlado por Pedro Corbí (Castalla, Onil, Tibi, Ibi, Biar, Petrer, Monovar y Bañeres) obtuvieron del monarca el máximo reconocimiento al otorgarles el título de Muy Nobles, Fieles y Leales «por su singular fidelidad, amor y celo a mi Real persona, que unánimes y conformes protestaron cuando la rebelión de aquel Reino» ${ }^{106}$, además de confirmar la licencia concedida por Corbí a sus vecinos de poder portar armas, y la ratificación de todos los privilegios y gracias que tuvieren «en cuanto no se opongan a la Nueva Planta de gobierno» ${ }^{197}$.

En zonas donde el apoyo al austracismo fue notable, el número de exiliados borbónicos que hemos localizado es escaso. Cocentaina se unió al bando austracista por atender Basset a su petición de dejar de ser señorío y pasar a villa de realengo. Su gobernador, el alcoyano Tomás Capdevila, no pudo evitar la deserción de los vecinos: «Trabajó cuanto pudo y era de su obligación para que aquellos naturales se mantuviesen debajo del feliz y suave dominio de V. M., como lo consiguió hasta que apoderados los sediciosos y los enemigos del Reino, con la ciudad de Valencia, se dejaron ir los de aquel condado». Tuvo que soportar la violencia antiseñorial, dirigida hacia su residencia de gobernador del señorío, que fue saqueada con «furor», «para vengar su rabia por la fídelidad y amor al servicio de V. M. con que le miraban $\rangle^{198}$. Su exilio en Madrid estuvo repleto de dificultades, pues tenía mujer y ocho hijos, y pese a recibir en diciembre de 1706 un socorro de 50 doblones, en mayo de 1707 pedía ayuda para volver a su Alcoy natal para

192. A. H. N. Consejos Lib. 2.494, ff. $157 \mathrm{v}-161$.

193. Gacetu de Madrid 29 de agosto de 1747.

194. A. H. N. Consejos Leg. 18.746 Memorial de D. Francisco García Ibáñez. Pasó al Consejo de Aragón el 17 de febrero de 1707 .

195. A. H. N. Consejos Leg. 18.746 Memorial de D. Raimundo Casamayor.

196. A. H. N. Consejos Lib. 2.494, ff. $180 \mathrm{v}-183$.

197. A. H. N. Consejos Lib. 2.494, ff. 188.

198. A. H. N. Consejos Leg. 18.476 Memorial de D. Tomás Capdevila. 
no morir de hambre ${ }^{199}$. De la vecina Alcoy, que pronto reconoció al Archiduque ${ }^{200}$, sólo sabemos de dos de sus vecinos que se exiliaron a Castilla. Diego Capdevila Cárdenas abandonó la villa nada más proclamar rey a $\mathrm{D}$. Carlos, y pasó a servir como voluntario en el regimiento de carabineros de Órdenes, hasta que «no pudiéndose sostener con el corto sueldo de la plaza» pasó a Madrid a la espera que Valencia volviera a la obediencia del rey Felipe $^{201}$, y Laureano Ayz, probablemente familiar del justicia electo en 1706 Ambrosio Ayz, y miembro de uno de los linajes alcoyanos que tuvieron con frecuencia responsabilidades en el gobierno municipal durante los siglos XVI y XVII.

En Onteniente, que fue saqueado tanto por borbónicos como por austracistas, destacó por su lealtad la familia Sancho, que tradicionalmente había ocupado cargos en el gobierno municipal. Gaspar Juan Sancho durante la revuelta de 1693 había asistido con hombres a su costa al gobernador de Xátiva, Ventura Ferrer, para sofocar la revuelta campesina, y cuando en 1705 tuvo noticia de la toma de Denia, al contar ya con 80 años de edad, envío a sus hijos Jerónimo y José a Gandía para ponerlos al servicio de las autoridades que intentaban oponerse a la propagación del austracismo. Cuando Francisco García de Ávila atacó Onteniente en diciembre de 1705 intentó que fuerzas procedentes de Castilla socorrieran la villa, «pero como la mayor parte de aquel pueblo se hallaba infecto y codicioso por el robo, fue ninguna su resistencia, y quedó ocupada la villa por los sediciosos $\rangle^{202}$. Gaspar y sus hijos huyeron a Hellín, sin poder sacar de la villa a sus familias. Jerónimo y José se pusieron a las órdenes del obispo Belluga en Villena, y acompañando a sus tropas recuperaron Onteniente y la saquearon, "siendo los primeros que ocuparon el convento de San Francisco a fuerza de armas». Cuando Onteniente se rindió definitivamente al ejército borbónico el 28 de abril de 1707 las autoridades militares designaron a José Sancho nuevo Justicia, y con la instauración del nuevo municipio, tanto José como Jerónimo fueron nombrados regidores. El 20 de febrero de 1709 un Real Decreto concedió a Gaspar Sancho, que había solicitado el título de marqués en diciembre de 1706, escudo de armas en el que debía figurar «un brazo armado que tiene una flor de lis en campo de otro con el mote de la orla que dice tenui eum, nec dimitan», como reconocimiento a su fidelidad ${ }^{203}$.

Orihuela y Elche, en la frontera sur valenciana, fueron las primeras poblaciones de entidad recuperadas por el ejército borbónico, pues Orihuela fue tomada y saqueada el 10 de octubre de 1706, y Elche el 21 de ese mismo mes por Berwick. Más que sentimiento favorable al Archiduque otras motivaciones incidieron en la proclamación como rey de D. Carlos por estas dos localidades. En Orihuela, las malas relaciones entre el obispo Belluga y el marqués de Rafal, gobernador borbónico de Orihuela,

199. A. H. N. Consejos Leg. 18.450 Memorial de D. Tomás Capdevila. Pasó al Consejo de Aragón el 18 de mayo de 1707.

200. Rogelio SANCHIS LloRENS: Alcoy y la Guerra de Sucesión, 1700-1709, Alicante 1969, pp. 51-74.

201. A. H. N. Consejos Leg. 18.450 Memorial de Diego Capdevila Cárdenas.

202. A. H. N. Consejos Leg. 18.476 Memorial de D. Gaspar Juan Sancho. Pasó al Consejo de Aragón el 24 de diciembre de 1706.

203. A. H. N. Consejos Lib. 2.494, ff. $278 \mathrm{v}-280 \mathrm{v}$. 
influyeron en que este último se pasara al austracismo en julio de $1706^{204}$, además de pesar las seculares diferencias de vecindad entre oriolanos y murcianos ${ }^{205}$, lo que sirvió de justificación al magistral de la catedral oriolana en el momento de suplicar el perdón de Felipe $\mathrm{V}$ pues, en su opinión, la desafección de la ciudad se debió «no a falta de amor a S. M., sino a la antigua displicencia con que siempre habían mirado los naturales de Orihuela a los de Murcia y su Reino, y a las frecuentes amenazas que al presente proferían de saquearles sus bienes, y talar y abrasar sus haciendas ${ }^{206}$. En Elche, su condición de señorío del duque de Arcos y el deseo de recuperar su condición de villa realenga, fue un elemento determinante, y por ello la violencia se dirigió contra el gobernador Vitorino Durán Gámir quien «fue robado y desterrado por los enemigos, y obligado a abandonar su crecida familia de mujer y ocho hijos sin tener modo de asistirlas $\rangle^{207}$.

En Orihuela, sólo una pequeña parte de la pequeña nobleza local, con intereses agrarios y jurisdiccionales, abandonó la ciudad tras la desafección del marqués de Rafal, y se refugió en Murcia. Lo hicieron Luis Togores, que era señor de Jacarilla ${ }^{208}$, y Jerónimo Rocamora, que lo era de Benferri, cuya hacienda fue saqueada y quemada, aunque Rocamora se encontraba en la Corte en 1706 por razones de pleitos con los jesuitas ${ }^{209}$. La falta de borbónicos acreditados en Orihuela fue causa de las dificultades para la configuración de su primer ayuntamiento ${ }^{210}$. Además de Togores y Rocamora sólo hemos localizado los memoriales del abogado Luis Maseras, que formó parte de la bolsa de insaculados de mano menor, Pedro Monserrat, que permaneció en Orihuela, aunque sufriendo «muchas extorsiones y vejaciones», y que por ello fue nombrado por Belluga secretario y archivero de la ciudad en diciembre de 1706, Adrián Viudes, que obtuvo privilegio de hidalguía en 1709 «por dos vidas»»"11, y padre del regidor Juan Francisco Viudes, Tomás Botella, escribano de la gobernación, y encarcelado por orden del marqués de Rafal al negarse a reconocer al Archiduque, y Blas de Cartagena,

204. Sería nombrado Gentilhombre de Carlos III, Virrey de Mallorca en 1709, y Consejero de Estado en Viena. Sobre el papel del Reino de Murcia en la contienda como frontera con la Valencia austracista, vid. Francisco Javier Gulllamon Alvarez y Julio D. MuÑoz Rodríguez: «Los castellanos y la Guerra de Sucesión: disciplina social y orden político en la Corona de Castilla (1680-1714)», en Cheiron 39-40 (2003), pp. 105-128.

205. Juan Bautista VILAR: Orihuela, una ciudad valenciana en la España moderna, Murcia 1981, pp. 677684 .

206. Alfonso PARDo y Manuel de VILLENA: El marqués de Rafal y el levantamiento de Orihuela en la Guerra de Sucesión (1706), Madrid 1910, p. 46.

207. A. H. N. Consejos Leg. 18.476 Memorial de D. Vitorino Durán Gámir. Aun cuando Berwick, cuando recuperó Elche, le ordenó regresar a Elche, en febrero de 1707 solicitó el gobierno de Castellón.

208. Jesús MiLlan y García-VARela: Rentistas y campesinos. Desarrollo agrario y tradicionalismo politico en el sur del País Valenciano, 1680-1840, Alicante 1984, p. 128.

209. A. H. N. Consejos Leg. 18.476 Memorial de D. Jerónimo Rocamora. Rocamora se hallaba en Madrid desde 1703 pleiteando con la Compañía de Jesús por la sucesión del señorío de la Granja.

210. María del Carmen IRLES VICENTE: El régimen municipal...p. 81-83.

211. A. H. N. Consejos Lib. 2.494, ff. 305-314. 
alguacil mayor del Real Patrimonio de la bailía de Orihuela, y que recibió el título vitalicio de alguacil mayor de sacas y millones de la ciudad en atención «a lo que ha padecido durante las turbaciones pasadas en su persona y casa $»^{212}$. El cargo de escribano del ayuntamiento de la ciudad tuvo que recaer en Ramón Arboleda, hermano de José Arboleda, médico de la real familia, ambos ausentes de su ciudad natal durante la guerra ${ }^{213}$.

\section{ECLESIÁSTICOS CONTRA LA SEDICION Y LA HEREJIA}

Es sabido que una parte importante del clero valenciano apoyó la causa del Archiduque, y contribuyó de manera decisiva a su éxito en los primeros momentos del levantamiento ${ }^{214}$, pero hay que considerar que también el estamento eclesiástico vivió, como el resto de la sociedad valenciana, una fuerte polarización. Muchos marcharon al exilio, tras identificar al austracismo como enemigo de la fe y denunciar el peligroso contagio que suponía el apoyo de protestantes holandeses e ingleses con sus ejércitos de herejes $^{215}$. Fray Vicente Ferrer, lector de teología en el convento de Predicadores de Valencia, es representativo de ese clero minoritario valenciano que consideraba que se habían coaligado contra Felipe $\mathrm{V}$ el infierno, la herejía y la sedición, y que había que clamar desde el púlpito, el confesionario o en las conversaciones «contra tan execrable maldad, enseñando que eran incapaces de la absolución cuantos deseaban y procuraban tan diabólica novedad, por traidores, perjuros, fautores de herejes y reos de innumerables daños, y un abismo de sacrilegios que consigo lleva una guerra tumultuaria, civil y contra religión $\rangle^{216}$. Ferrer fue uno de los eclesiásticos expulsados por el virrey Cardona en agosto de 1706, acusado, según se indicaba en el auto de destierro, de introducir el escándalo de que «no se podía rogar por la salud de la Real persona, ni por la felicidad de los progresos de sus Católicas Armas, entibiando por este camino tan desviado de la Ley de Nuestro Señor a los afectuosos vasallos que han admitido gustosos el suave yugo de su legítimo rey, deseado y esperado con ansía. Y otros han elegido el publicar novedades fabulosas contrarias a las continuas misericordias que la Divina omnipotencia difunda en dicha Real persona, que acreditan haberla destinado para monarca de estos dos Católicos Mundos, asegurando con este medio que se aumente el partido de los descontentos y malos vasallos. Y también se han señalado por desafectos en las juntas privadas que entre aquellos se tienen, apartándose de los más apasionados y fieles vasallos de S. M. De lo que han resultado, y resultan, escándalos, y peligra la paz y quietud pública, y

212. A. H. N. Consejos Lib. 2.494, ff. $135 \mathrm{v}-137$ Real Cédula concediendo titulo vitalicio de Alguacil Mayor de Sacas y Millones de la ciudad de Orihuela, Madrid 2 de mayo de 1708.

213. A. H. N. Consejos Lib. 2.494, ff. 22-23v Titulo vitalicio de Escribano del Ayuntamiento de Orihuela, Madrid 22 de octubre de 1707.

214. Carmen PÉrez APARICIO: «El clero valenciano a principios del siglo XVIII: la cuestión sucesoria», en Estudios de Historia de Valencia, Valencia 1977, pp. 247-278.

215. David GONZALEZ CRUZ: Guerra de religión entre príncipes católicos. El discurso del cambio dinástico en España y América, Madrid 2002, pp. 23-70.

216. A. H. N. Consejos Leg. 18.450 Memorial de Fray Vicente Ferrer O. P. 
hay eminente peligro de daños irreparables $\rangle^{217}$. Le acompañó su hermano de comunidad Fray Domingo Rioja, que había defendido en el púlpito la justicia de los derechos de Felipe $\mathrm{V}$ a la corona ${ }^{218}$. También fueron desterrado Fray José Güell, dominico de Santo Domingo de Orihuela, «por imprimir en los corazones de los oyentes de sus sermones, y en lo que confesaba, las razones tan sagradas que justifican el verdadero dominio» de Felipe $\mathrm{V}^{219}$, y Fray Francisco Milán de Aragón, hermano del marqués de Albaida, que había sido provincial de la orden dominica, y catedrático de teología en la Universidad de Valencia entre 1670 y $1702^{220}$ por «haber levantado el grito a la execrable resolución de tomar las armas sus religiosos contra la Real persona de V. M., y a fin de cumplimentar a los herejes que entraron en dicha ciudad de socorro, le desterraron de aquellos países rebeldes, dándole sólo veinticuatro horas de tiempo para ejecutar su partenza, lo que cumplió sin poder sacar más de lo preciso para su avío ${ }^{221}$. Milán se refugió en un convento de Castilla «mientras durare la tempestad que la descabellada malicia del demonio ha suscitado contra Dios y contra V. M.», haciéndose eco de la muy extendida tesis de la conjura de Lucifer, las potencias protestantes y el Archiduque contra el rey legítimo y católico monarca, y que se resumía en cuartetos que decían "Que a pesar de Lucifer/y de toda su cuadrilla/ la corona de Castilla/ para Felipe ha de ser ${ }^{222}$. Fray Francisco Oriente, sacristán del convento de los dominicos de Alicante, se refería a los ingleses como «enemigos de Dios y de la Iglesia», lo que, en su opinión, quedaba probado por el trato que le dispensaron cuando ocuparon Alicante, quitándole los hábitos y dejándole desnudo ${ }^{223}$. Algunos frailes jerónimos del monasterio valenciano de San Miguel de los Reyes también fueron desterrados a Castilla por el virrey Cardona con similares motivos el 9 de septiembre de 1706, con prohibición expresa de dirigirse a Aragón ${ }^{224}$. Por utilizar el púlpito para desengañar a los fieles «del error que cometían contra la Ley de Dios y contra el debido vasallaje» fueron expulsados de aquel monasterio los padres Diego Vidal, Vicente Aparicio, Bernardo Cortés, Vicente de San Miguel, Juan de Toro, Juan Bautista Gandía, Pedro Ibáñez y el Dr. José Sánchez, que pasaron a San Clemente, en Cuenca ${ }^{225}$. Otros vagaron durante meses, «peregrinando

217. A. H. N. Consejos Leg. 18.450 Auto de destierro de Fray Vicente Ferrer, Valencia, 25 de agosto de 1706.

218. Fray Domingo Rioja solicitó el título de Predicador Real, en A. H. N. Consejos Leg. 18.476 Memorial de Fray Domingo Rioja. Pasó al Consejo de Aragón el 27 de mayo de 1707.

219. A. H. N. Consejos Leg. 18.476 Memorial de Fray José Güell O. P. Pasó al Consejo de Aragón el 2 de febrero de 1707.

220. Amparo FELIPO ORTS: La Universidad de Valencia...p. 432.

221. A. H. N. Consejos Leg. 18.450 Memorial de Fray Francisco Milán de Aragón O. P.

222. Véase el texto «Lucifer en visita y el diablo en residencia», editado en María Teresa PÉREz PICAZO: La publicistica española en la Guerra de Sucesión, Madrid 1966, vol. II, pp. 121-142.

223. A. H. N. Consejos Leg. 18.476 Memorial de Fray Francisco Oriente O. P.

224. Vicente Graullera: Op. Cit. pp. 71-72.

225. Fray Diego Vidal solicitó plaza de Predicador Real, en A. H. N. Consejos Leg. 18.476 Memorial de Fray Diego Vidal. Pasó al Consejo el 8 de mayo de 1707. 
de un lugar a otro», antes de poder llegar a la Corte, como narraba el carmelita calzado Fray Vicente Agramunt, expulsado de Valencia el 25 de agosto de 1706, o el trinitario Fray Bartolomé Casas, que «salió con gran incomodidad de la ciudad de Valencia huyendo de la furia de los malcontentos que pretendían prenderlo por su nunca disimulada fidelidad y declarado amor» a Felipe V. Casas se dirigió a Zaragoza, y tuvo nuevamente que huir, «y no hallando ya en toda la provincia de Aragón convento suyo que no estuviese ya en poder de los enemigos se fue a Atienza, donde incorporándose con el Real Ejército le siguió hasta que S. M. se restituyó a su Corte, donde hasta ahora se ha mantenido, y mantiene, con suma estrechez y necesidad, pues sus hábitos de pobre pasan ya a indecentes $\rangle^{226}$. La mayor parte de religiosos valencianos residieron en Madrid en conventos de sus respectivas órdenes, pero su situación se agravaba cuando no disponían de lugar donde ser acogidos. Fray Juan Bautista Borbón, religioso de los Siervos de María Santísima en Murviedro, vivió en Madrid «con suma miseria» al no tener convento su orden en la Corte ${ }^{227}$, y el fraile jerónimo Juan Bautista Blasco, tras huir de Valencia «a pie, cruzando montes y barrancos», sólo pudo refugiarse en un monasterio de su orden en Segovia.

La Compañía de Jesús fue mayoritariamente borbónica, siguiendo la línea marcada por su General Tirso González, aunque tanto Felipe V como el Archiduque contaban con confesor jesuita ${ }^{228}$, y algún miembro relevante de la orden fue austracista, como el P. Álvaro Cienfuegos, que llegó a cardenal. El 25 de agosto de 1706 el conde de Cardona ordenó que todos los padres de la Casa Profesa de Valencia debían abandonar la ciudad en el plazo de 24 horas, y de seis días para que salieran del Reino ${ }^{229}$. El rector del colegio de Orihuela hizo una relación de las vejaciones, prisiones y destierros que padeció la comunidad durante la ocupación austracista de la ciudad, y el saqueo de dos de sus haciendas, con pérdidas de 400 fanegas de trigo y 600 de cebada. Todos los jesuitas de Orihuela fueron recluidos en Callosa de Segura, y tres fueron desterrados porque el colegio oriolano fue destinado a residencia de 400 soldados llegados de Cartagena. Cuando la ciudad fue conquistada por Belluga, nuevamente las propiedades del colegio fueron saqueadas, pero en esta ocasión, decía su rector, los jesuitas «lo toleraron con alegría por juzgar inevitable el primer ímpetu de las tropas, y dieron por bien empleada la pérdida de lo poco que les quedaba por considerarse restituido al suave dominio de V. M. $\gg^{230}$. Actitud tan comprensiva fue premiada por el obispo Belluga con

226. A. H. N. Consejos Leg. 18.476 Memorial de Fray Bartolomé de las Casas. Solicitó ser honrado con el título de Predicador Real. Pasó al Consejo el 16 de marzo de 1707, y fue recomendado para Predicador, al tiempo que se le daba una limosna «con que subvenir la falta de vestidos que del todo le estrecha».

227. A. H. N. Consejos Leg. 18.450 Memorial de Fray Juan Bautista Borbón. Solicitaba socorro para poder vestirse y regresar a Murviedro en junio de 1707.

228. Julián J. Lozano NaVARro: La Compañia de Jesís y el poder en la España de los Austrias, Madrid 2005, pp. 376-377.

229. Vicente Graullera: Op. Cit. pp. $71-72$.

230. A. H. N. Consejos Leg. 18.476 Memorial deL Rector del Colegio de la Compañia de Jesús de Orihuela. Pasó al Consejo el 5 de febrero de 1707. 
la entrega de 50 fanegas de trigo y la donación de dos casas de relevantes austracistas, como el marqués de Rafal y Esteban León, aunque la Compañía solicitó que el colegio quedara exento de toda contribución o alojamientos.

El arzobispo de Valencia, Antonio Folch de Cardona, hijo natural del Almirante de Aragón ${ }^{231}$, el obispo de Orihuela, José de la Torre Orumbella, y el de Tortosa, con jurisdicción sobre tierras valencianas, Silvestre García Escalona, abandonaron sus diócesis cuando sus sedes pasaron a control austracista. Folch se trasladó a Madrid, acompañado de una nutrida familia episcopal, y el Consejo de Aragón decidió no incluir a sus integrantes en el reparto de socorros porque de hacerlo «no quedaría para tanto necesitado ${ }^{232}$. El arzobispo valenciano mantuvo una cierta ambigüedad en los primeros momentos de la revuelta, que lo hicieron sospechoso a ojos del virrey Villagarcía, hasta el punto que de fue amonestado por Felipe $\mathrm{V}$ y amenazado con que el Virrey podría asumir la jurisdicción eclesiástica si no endurecía su actitud hacia el clero desafecto, especialmente los franciscanos, la orden del propio arzobispo: «...procedáis en lo que tocare como lo espero y que no será necesario valerme yo de otros medios para atajar el daño que se ha experimentado en esta ocasión, porque mi Real ánimo es que en caso de no hacerlo vos, pase mi lugarteniente y capitán general a proceder contra los eclesiásticos desafectos por los medios permitidos a la Real potestad, como al mismo tiempo de escribiros ésta, se lo he ordenado y os prevengo de ello para que lo tengáis entendido ${ }^{233}$. En 1710, en momentos que parecía que la victoria podría inclinarse a favor del Archiduque, Folch de Cardona, que se encontraba en Madrid desde 1709 para la jura del infante D. Luis como príncipe de Asturias, abrazó tardíamente su causa, lo que le valió su exilio definitivo en Viena, donde murió en 1724. José de la Torre se refugió en Murcia con todo su cabildo, excepto su deán, Francisco Rocamora ${ }^{234}$, en sintonía con el obispo de aquella diócesis, Belluga, pues ambos consideraban el conflicto sucesorio como guerra de religión ${ }^{235}$. Escalona, refugiado en Madrid, solicitó una ayuda de costa para regresar a su diócesis antes de que Tortosa fuese recuperada en 1708 «por tener la mayor parte de ella en el Reino de Valencia ${ }^{236}$. Sólo el obispo de Segorbe, Antonio Ferrer Milán, reconoció al Archiduque, y por ello tuvo responsabilidades en la confiscación de bie-

231. Conxita MOlLfulleda I VINYALLonGA: «Antoni Folch de Cardona», en Catalunya durant la Guerra de Successió, Badalona 2006, vol. III, pp. 108-109.

232. A. H. N. Consejos Leg. 18.450 Manrique de Lara a Grimaldo, Madrid 15 de diciembre de 1707.

233. A. H. N. Consejos Leg. 18.438 El Rey al Arzobispo de Valencia, 30 de junio de 1704.

234. La Junta del Breve le exculpó de la acusación de austracista, en Juan C. SAAVEDRA ZAPATER: «La incorporación a España del clero exiliado durante la Guerra de Sucesión: una aproximación a su estudioł, en El cambio dinástico y sus repercusiones en la España del siglo XVIII, Jaén 2000, pp. 479-496.

235. Francisco de Castellvi: Op. Cit. vol. II, p. 53.

236. A. H. N. Consejos Leg. 18.476 Memorial de D. Silvestre García Escalona, Obispo de Tortosa. Pasó al Consejo el 6 de junio de 1707. 
nes a eclesiásticos borbónicos ${ }^{237}$, al igual que los obispos aragoneses de Albarracín y Huesca, austracistas, frente a los prelados de Zaragoza y Tarazona, borbónicos ${ }^{238}$.

Algunas dignidades exiliadas estaban emparentadas con las grandes familias valencianas que también se habían refugiado en Castilla. José Castelví y Antonio Milán de Aragón eran canónigos de la metropolitana de Valencia, y el primero gozaba del privilegio de ser sumiller de cortina de Felipe V. Antonio Milán había levantado a sus expensas varios tercios de infantería, y cuando abandonó Valencia dejó atrás no únicamente la renta de su prebenda, sino dos beneficios en Elche que le producían anualmente 3.000 ducados. Cuando pasó a Utiel, lo esperaba su hermano el marqués de Albaida, y juntos se refugiaron en Madrid «por el recelo de que las tropas del enemigo, que se hallaban en los lugares de aquella vecindad, no les prendiesen». Para mantenerse en la Corte decentemente con su criado, el Consejo de Aragón le hizo merced de 400 ducados de pensión eclesiástica sobre el arzobispado de Valencia, y la hizo extensiva a la primera vacante que se produjera en las diócesis de Orihuela o Segorbe ${ }^{239}$.

Algunos eclesiásticos seculares habían intervenido apoyando a las tropas, no sólo con su auxilio espiritual, sino con las armas en la mano, lo que no fue raro en la contienda, pues en Tarazona se formó un regimiento de eclesiásticos, bajo las órdenes de sus canónigos, y en Valencia los capuchinos de la capital intervinieron directamente en la lucha ${ }^{240}$. El sacerdote alicantino José Ibarra Paravecino fue hecho prisionero por su condición de capellán de las milicias que defendían el castillo de Alicante, y el sacerdote de Bocairente Jerónimo Alcaraz acompañó a las tropas del conde de las Torres confesando soldados, y las mismas funciones desempeñó posteriormente en el ejército de Belluga. El sacerdote Salvador Sales, que era comisario del Santo Oficio en Valencia, acudió a la defensa de una de las puertas de la ciudad y, después, a la casa de la Inquisición, para «librarla del ciego furor de los rebeldes, que intentaron maltratarla, y aún mudarla». En febrero de 1706 salió de Valencia «con disfraz de paisano» y a pie hasta Villamarchante, donde informó al conde de las Torres de la situación valenciana y de la llegada de Peterborough el día 4 de febrero. En Madrid se dedicó a malvivir y a pretender alguna plaza en el Consejo de Inquisición ${ }^{241}$. Ignacio Corbí, sobrino del líder borbónico Pedro Corbí, abandonó Alcira después de que sus predicaciones contra los austracistas, tachándolos de herejes, le causaran graves inconvenientes. Siguió a Felipe $V$ hasta Jadraque, «en donde tuvo un balazo que le rompió una pierna», y fue socorrido

237. Carmen PEREZ APARICIO: «La Guerra de Sucesión en España», en La transición del siglo XVII al XVIII, vol. XXXVIII de la Historia de España de Ramón Menéndez Pidal, Madrid 1994, p. 411.

238. Ángela ATIENZA LóPEZ: «El clero de Aragón frente al conflicto sucesorio», en Eliseo SERRANo (ed.): Felipe $V$ y su tiempo, Zaragoza 2004, vol. I, pp. 375-396.

239. A. H. N. Consejos Leg. 18.476 Memoriales de D. Antonio Milán de Aragón. Pasaron al Consejo el 7 de enero y al 8 de julio de 1707 .

240. Antonio Luis CORTeS PEÑa: «La Iglesia y el cambio dinástico», en Eliseo SERRANo (ed.): Felipe Vy su tiempo, Zaragoza 2004, vol. I, pp. 991-1012. La referencia en p. 1005.

241. A. H. N. Consejos Leg. 18.476 Memorial de D. Salvador Sales. Pasó al Consejo el 23 de mayo de 1707. 
con 600 rls. para evitar que muriera de hambre ${ }^{242}$. Como Corbí, también era natural de Ibi el sacerdote Paulino San Juan, que empuñó las armas en las milicias que Pedro Corbí levantó en la Hoya de Castalla, y se convirtió en uno de sus hombres de confian$\mathrm{za}$, participando en las acciones de guerra en las que aquel intervino. También Jacinto Traber, sacerdote de Onteniente, comenzó como capellán del regimiento que formó en la villa su hermano Mateo Traber para recuperar Denia, pero al fracasar y disolverse esa milicia, ambos decidieron ingresar en las tropas del obispo Belluga, guiándolas en su ataque y saqueo de Onteniente. Hecho prisionero en Xátiva, fue encarcelado «con una cadena al cuello y grillos en los pies», y fue puesto en libertad por las gestiones del vicario general que hizo valer su condición de sacerdote ${ }^{243}$. Pedro Checa Mateo abandonó la carrera eclesiástica por la militar, participando activamente en los sitios de Alcira y Xátiva. Pero lo más habitual era encontrar en la Corte a sacerdotes que habían abandonado Valencia a pie, por caminos poco transitados o campo a través, por «no macularse con aquella rebelión, como por mantenerse bajo el suave, cuanto apacible, dominio de V. M.», como señalaba en su memorial el beneficiado de la parroquia de San Martín de Valencia, Francisco Marín, y que se mantenían con el socorro de las misas $y$, en muchos casos, «el arrimo de caballeros valencianos», en una comunidad de exiliados que esperaban con ansia el triunfo de su rey que les permitiría el regreso a su patria y el premio correspondiente a su fidelidad, pues son frecuentes los decretos remitidos a los obispos valencianos para que los prelados tuvieran presentes en ascensos «propios de su ministerio» a aquellos eclesiásticos que hubieran manifestado de forma notable «la fidelidad a mi Real persona, cumpliendo con las obligaciones de buen vasallo» ${ }^{244}$.

242. A. H. N. Consejos Leg. 18.450 Memorial de D. Ignacio Corbi. Pasó al Consejo el 7 de abril de 1707. 243. A. H. N. Consejos Leg. 18.450 Memorial de D. Jacinto Traber.

244. Sirva como ejemplo el sacerdote de la parroquial de Onteniente Vicente Colomer, que se vio forzado a dejar su parroquia y a exiliarse en la Corte, donde vivió endeudado hasta que pudo regresar a Almansa primero, y posteriormente a Onteniente, «con los notorios atrasos que le han ocasionado sus trabajos». Un decreto, firmado el 18 de junio de 1708, ordenaba al Arzobispo de Valencia que lo tuviera presente para ascensos por su fidelidad de buen vasallo, en A. H. N. Consejos Lib. 278 ff. $9 \mathrm{v}-10$. 